$$
1 \text { किष } 11
$$

$$
\text { 1) you }
$$

㕵

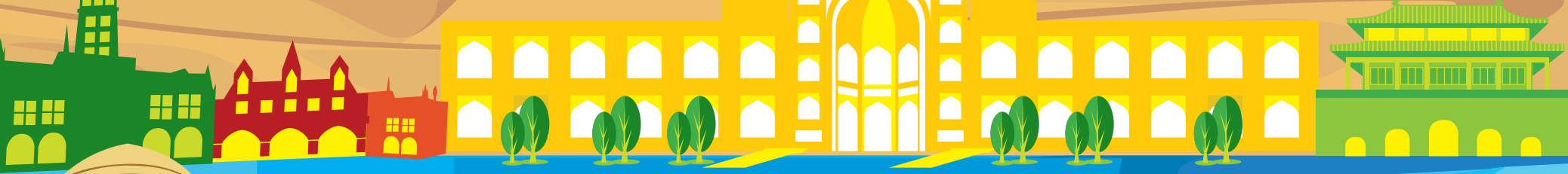

लिaि

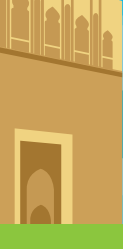

PROMOTING REGIONAL

TOURISM COOPERATION

UNDER CAREC 2030

A SCOPING STUDY

MARCH 2019 



\section{PROMOTING REGIONAL TOURISM COOPERATION UNDER CAREC 2030}

\section{A SCOPING STUDY}

MARCH 2019 
(C) 2019 Asian Development Bank

6 ADB Avenue, Mandaluyong City, 1550 Metro Manila, Philippines

Tel +632632 4444; Fax+6326362444

www.adb.org

Some rights reserved. Published in 2019.

ISBN 978-92-9261-536-9 (print), 978-92-9261-537-6 (electronic)

Publication Stock No. TCS190047-2

DOI: http://dx.doi.org/10.22617/TCS190047-2

The views expressed in this publication are those of the authors and do not necessarily reflect the views and policies of the Asian Development Bank (ADB) or its Board of Governors or the governments they represent.

ADB does not guarantee the accuracy of the data included in this publication and accepts no responsibility for any consequence of their use. The mention of specific companies or products of manufacturers does not imply that they are endorsed or recommended by ADB in preference to others of a similar nature that are not mentioned.

By making any designation of or reference to a particular territory or geographic area, or by using the term "country" in this document, $\mathrm{ADB}$ does not intend to make any judgments as to the legal or other status of any territory or area.

This work is available under the Creative Commons Attribution 3.0 IGO license (CC BY 3.0 IGO)

https://creativecommons.org/licenses/by/3.0/igo/. By using the content of this publication, you agree to be bound by the terms of this license. For attribution, translations, adaptations, and permissions, please read the provisions and terms of use at https://www.adb.org/terms-use\#openaccess.

This CC license does not apply to non-ADB copyright materials in this publication. If the material is attributed to another source, please contact the copyright owner or publisher of that source for permission to reproduce it. ADB cannot be held liable for any claims that arise as a result of your use of the material.

Please contact pubsmarketing@adb.org if you have questions or comments with respect to content, or if you wish to obtain copyright permission for your intended use that does not fall within these terms, or for permission to use the ADB logo.

Corrigenda to ADB publications may be found at http://www.adb.org/publications/corrigenda.

Notes:

In this publication, “\$” refers to United States dollars.

ADB recognizes "China" as the People's Republic of China and "Russia” as the Russian Federation.

Cover design by Jasper Lauzon. 


\section{Contents}

Tables and Figure

iv

Preface

$\mathbf{v}$

Acknowledgments vii

Abbreviations

Executive Summary

viii

1 Introduction

1.1 Background to CAREC and its New Strategy and Objectives

1.2 The CAREC Region 2

1.3 Purpose and Structure of the Tourism Scoping Study 2

2 Current State of Tourism and Future Prospects 4

2.1 Demand Growth and Trends 4

2.2 Key Influences 6

3 Strengths, Weaknesses, Opportunities, and Threats Analysis 13

4 Building on Strengths and Capturing Opportunities 14

5 Addressing Weaknesses and Challenges 15

5.1 Appeal: Image and Brand Perception 16

5.2 Accessibility: Air and Land Connections, and Border Regulations 17 and Arrangements

5.3 Tourism Products

5.4 Standards and Service: Human Capacity Development and Facility Certification 25

5.5 Safety and Security: Medical and Rescue Facilities, and Policing 26

5.6 Institutional Arrangements for Tourism 26

6 Identification of Regional Tourism Cooperation Opportunities 29

6.1 National Policy and Planning Strategies and Action Plans 29

6.2 Existing Tourism Cooperation in the CAREC Region and Best Practices 30 from Other Regions

6.3 Potential Regional Tourism Clusters and Partnerships 33

6.4 Range of Regional Tourism Cooperation and Integration Opportunities 35

6.5 Tourism Product Development: the Importance of Market Knowledge 39 and Research

6.6 CAREC Regional Tourism Workshop: Survey Results 42

7 CAREC Regional Tourism Cooperation: Recommendations 43

Appendixes

1 Summaries of Tourism Priorities, Strategies, and Targets for CAREC Members 45

2 Greater Mekong Subregion Strategic Direction Programs 56

3 Thailand's System of Tourism Administration 57

4 Survey Results 58 


\section{Tables and Figure}

\section{Tables}

Summary of Recommendations

1 Forecasts of International Tourist Arrivals and Visitor Spending in CAREC Countries, 2018-2028

2 Populations and Gross Domestic Product Growth in CAREC Member States, $2017 \quad 7$

3 Key Trends in International Tourism 8

4 SWOT Analysis 13

5 Visa-Entry Arrangements between CAREC Countries 20

6 Visa-Entry Requirements for International Markets in CAREC Countries 20

7 Multicountry Tour Programs Offered from Europe to CAREC Countries 22

8 Tourism Priorities, Goals, Strategies, and Targets of CAREC Countries 40

9 Summary of Recommendations 43

\section{Figure}

Model of Nature-Based Tourism Demand 


\section{Preface}

This scoping study was prepared at the request of the member countries of the Central Asia Regional Economic Cooperation (CAREC) Program. The study seeks to assess the potential of CAREC as a platform to promote a regional approach to tourism development through the identification of opportunities for enhancing and expanding cooperation among member countries in the tourism sector, and to maximize economic opportunities while safeguarding ecosystems.

The CAREC Program is a partnership of 11 countries-Afghanistan, Azerbaijan, Georgia, Kazakhstan, the Kyrgyz Republic, Mongolia, Pakistan, the People's Republic of China (the PRC), Tajikistan, Turkmenistan, and Uzbekistan—supported by development partners, working together to promote development through cooperation, leading to accelerated growth and poverty reduction.

The 16th Ministerial Conference in October 2017 was a cornerstone event for the CAREC Program as it involved the ministers' endorsement of a new CAREC strategy leading to 2030. CAREC 2030 is anchored on a mission to connect people, policies, and projects for shared and sustainable development, serving as the premier economic and social cooperation platform for the region. In support of a broader mission, CAREC expanded its operational priorities under the new strategy to better address the region's development needs and help its member countries achieve the 2030 Global Development Agenda. The results of this sustained effort to promote regional cooperation and integration are expected to include better dialogue, increased peopleto-people exchanges, more economic ties, and improved connectivity throughout the region. ${ }^{1}$

Tourism development is one of the operational priorities under CAREC 2030. CAREC countries enjoy great potential for tourism, which is a major generator of jobs, particularly for workers at the middle to lower end of the income scale, and for women and the youth. Sustainable tourism, including community-based and urban tourism, and nature and ecotourism, provides particularly important opportunities. Given member countries' binding cultural ties and arresting natural endowments, including areas and routes rich in history and nature attractions that traverse national boundaries, CAREC can play a key role in unlocking the region's large untapped tourism potential. Initiatives that could be considered to promote tourism cooperation include investing in tourism services and infrastructure, jointly developing tourist products, advertising and branding, and advocating harmonization and relaxation of visa regimes, among others (footnote 1). 
To better understand CAREC's potential role in the tourism sector, a workshop was held in Tashkent in October 2018 at which participants assessed and expanded on regional cooperation opportunities identified in this preliminary document for inclusion in the final scoping study. Selected elements of their contributions, and those of the United Nations Educational, Scientific and Cultural Organization (UNESCO), are incorporated in the scoping study's analyses and recommendations. Results of a survey conducted with workshop participants are also presented in full in Appendix 4. 


\section{Acknowledgments}

This study was undertaken on behalf of the Central Asia Regional Economic Cooperation (CAREC) Secretariat and the Asian Development Bank (ADB). The team would like to thank Werner Liepach, Director General, Central and West Asia Department (CWRD); Yong Ye, Director, Urban Development and Water Division; and Safdar Parvez, Director, Regional Cooperation and Operations Coordination Division, CWRD, for the overall guidance.

The CAREC Secretariat at ADB administered and managed the production of this scoping study. The Secretariat team supporting CAREC tourism work includes Guoliang Wu, senior regional cooperation specialist and CAREC unit head; Ramola Naik Singru, senior urban development specialist; Carmen Garcia Perez, regional cooperation specialist; and Jennifer Lapis, CAREC regional cooperation coordinator.

The team expresses its appreciation to the regional cooperation coordinators and national focal points' advisors of all CAREC countries for the assistance extended in collecting relevant information from their respective countries and organizing the regional consultation workshop. The team would also like to extend its gratitude to all participants of the tourism workshop for their valuable inputs.

The principal author of this study is Robert Travers. The contributions of all CAREC member countries and of the United Nations Educational, Scientific and Cultural Organization (UNESCO) are acknowledged. Robert Cleverdon provided peer review and additional inputs. 


\section{Abbreviations}

$\begin{array}{ll}\text { ABEC } & \text { Almaty-Bishkek Economic Corridor } \\ \text { ADB } & \text { Asian Development Bank } \\ \text { ASEAN } & \text { Association of Southeast Asian Nations } \\ \text { AZN } & \text { Azerbaijan manat } \\ \text { CAREC } & \text { Central Asia Regional Economic Cooperation } \\ \text { EU } & \text { European Union } \\ \text { GDP } & \text { gross domestic product } \\ \text { GMS } & \text { Greater Mekong Subregion } \\ \text { IT } & \text { information technology } \\ \text { MICE } & \text { meetings, incentives, conferences, and exhibitions } \\ \text { PRC } & \text { People's Republic of China } \\ \text { SDG } & \text { Sustainable Development Goal } \\ \text { TA } & \text { technical assistance } \\ \text { UNESCO } & \text { United Nations Educational, Scientific and Cultural Organization } \\ \text { UNWTO } & \text { United Nations World Tourism Organization } \\ \text { US } & \text { United States } \\ \text { WTTC } & \text { World Travel and Tourism Council }\end{array}$




\section{Executive Summary}

\section{Introduction}

The purpose of the Central Asia Regional Economic Cooperation (CAREC) Program is to support socioeconomic growth in its member countries through cooperation and integration in development sectors. Endorsed at the 16th Ministerial Conference in October 2017, the CAREC 2030 strategy seeks to expand the horizons of economic cooperation in the region by connecting people, policies, and projects for shared and sustainable development. Given that the essence of tourism is to create and foster better dialogue, increased people-to-people exchanges, more economic ties, and increased connectivity throughout the region, its development is an operational priority under CAREC 2030.

Tourism is an activity in which its adherents do not feel constrained by national boundaries, but wish to pursue their interests or engage in chosen activities related to themes that can spread across multiple countries. Facilitating travel into, around, and between the countries of the CAREC region can bring significantly increased benefits.

Tourism has been recognized by the United Nations World Tourism Organization (UNWTO) as an effective way of helping developing countries achieve the Sustainable Development Goals (SDGs) and be more involved in the global economy. It can serve as an equalizing force and help bridge regional inequality gaps by fostering growth in urban and rural areas and providing an opportunity for local communities to flourish. Furthermore, promoting sustainable tourism can help preserve cultural heritage and support biodiversity conservation through waste reduction and other sustainable practices.

The aviation scoping study, recently completed under CAREC, identified the need for increased air connectivity to diversify access options. This tourism scoping study seeks to identify ways in which countries can work with each other to take advantage of the improved air access by increasing the appeal of the CAREC region, making it easier for tourists to enter and travel around the CAREC region, and developing infrastructure and things for tourists to see and do across two or more countries.

\section{Current State of Tourism and Future Prospects}

International tourism continues to show sustained and steady growth above the level of the global economy; and its rise shows few signs of slowing down with arrivals worldwide expected to increase by $3.3 \%$ a year between 2010 and 2030 , and to reach 1.8 billion by 2030 , according to the long-term forecast report Tourism Towards 2030 of the UNWTO. Between 2010 and 2030, 
arrivals in emerging destinations ( $+4.4 \%$ a year) are expected to increase at twice the rate of those in advanced economies $(+2.2 \%$ a year).

With the exclusion of Afghanistan, the Chinese Autonomous Regions of Inner Mongolia and Xinjiang Uygur, and Turkmenistan, the aggregate volume of international tourist arrivals in the CAREC region in 2018 is forecast by the World Travel and Tourism Council (WTTC) at just under 20 million with a predicted growth rate over the decade to 2028 of close to $5 \%$. In spite of this, taken in a global context, the aggregate share for CAREC countries (excluding the People's Republic of China) is less than $2 \%$ of world tourism.-

The determinants of the levels, directions, and types of international travel remain fairly constant, i.e., economic factors, demographic change, travel facilitation (both regulations and transport connectivity), tourism infrastructure and product development, and marketing and promotion. However, the way these influence on travel decisions have evolved over time, and the force of information technology continues to increase through greatly expanded consumer knowledge about destination and experience options, and the ways tourism products and services can be accessed and purchased. This has led to increased sophistication of marketing and promotional methods deployed by destinations and travel operators.

Two trends feature prominently in the current international tourism environment: (i) the consumer's search for greater self-fulfillment from their travel choices, and (ii) the instant and full availability of information on which to base such choices. One consequence of these trends is the selection of more off-the-beaten-track destinations, not recognized previously as primary tourism destinations, which can now position themselves to market segments which are specifically seeking the types of experience that CAREC countries can offer based on their individual natural and cultural resources. Future prospects for CAREC members will be determined both by external factors, such as economic performance and demographic changes in main (and secondary) tourist markets, and by measures which CAREC countries can takeeither individually, or through collaboration with other CAREC members and neighboring countries.

By providing opportunities for tourists from their own country and bordering countries, CAREC members will create socioeconomic benefits and pave the way for increasing foreign tourism in the medium to long term. The sequence of "domestic tourism-regional tourism-international tourism" has been an age-old model for tourism development and can apply appropriately to the CAREC countries. Given the CAREC countries' abundant natural and cultural heritage assets, the prevailing market trends augur well for increased tourist flows for activities such as:

(i) nature-based tourism in diverse forms, i.e., "hard" (adventure tourism), and "soft" (sightseeing);

(ii) cultural heritage tourism, exploiting the historically important Silk Road Route that runs through many CAREC countries and past civilizations, and combining tangible assets with the intangible ones of traditional crafts, music, performance, and food;

(iii) circuits combining both natural and cultural heritage features, catering to those with a general interest in these aspects of the CAREC countries;

(iv) city tourism (including transit tourism); 
(v) business tourism; and

(vi) event tourism.

\section{Building on Strengths and Capturing Opportunities}

The CAREC countries' strengths as tourism destinations arise from their natural and cultural heritage, and historical and built assets: (i) outstanding range of unspoiled natural resources in all countries; (ii) wide variety of cultural and urban tourism assets; (iii) UNESCO World Heritage Sites, the foremost being the Silk Road; (iv) diverse ethnic groups and cultures; (v) quality of lodging and other tourism facilities in capital cities; and (vi) political goodwill and support from governments for tourism development.

As a relatively new destination area, the CAREC countries can take advantage of market trends, while further exploiting the established reputation of the Silk Road by expanding the range of itineraries based on it. In capitalizing on the CAREC region's varied natural and cultural heritage strengths, it is vital that these are developed in ways that (i) are in line with the different strata of the tourism market's demands (i.e., domestic, interregional and international; leisure and nondiscretionary, and the various segments within these two categories); and (ii) provide maximum socioeconomic benefits to the host countries while minimizing deleterious sociocultural and environmental impacts, in line with the SDGs.

\section{Addressing Weaknesses and Challenges}

Several challenges currently hinder tourism development and cooperation in the CAREC region. These include insufficient air connectivity and inadequate transport infrastructure, complex visa regimes and cumbersome border crossing procedures, limited appeal of countries' tourism products, low quality of tourism standards, shortage of skilled workers, and weak branding and destination image of the region.

The success of any destination is a function of a combination of factors, including:

(i) Appeal: brand and image perception among consumers in target markets and segments;

(ii) Accessibility: capacity and quality of transport infrastructure; travel time, frequency and cost; entry requirements in the form of visas (ease and cost of obtaining); and border arrangements;

(iii) Tourism products: range and quality of things to see and do related to the market segments' interests;

(iv) Standards and service: quality of tourist facilities and service delivery of tourism personnel to internationally expected standards; and

(v) Personal safety: health facilities and policing to provide protection from civil and other crimes. 


\section{A. Appeal: Image and Brand Perception}

In tourism destination choice, it is important to recognize that prospective visitors' assessment and evaluation that will ultimately determine their selection are a combination of what they have learned from media (especially and increasingly social media) and word-of-mouth from travel agents, family, and friends. Not all this information may accurately reflect what the destination has to offer, but "the perception is the reality" when it comes to destination choice.

A prime example of how this process presents a challenge for the CAREC countries is the TripAdvisor report on Travel Trends for the Silk Road prepared with the UNWTO. Based on the report's traveler reviews, eight CAREC countries are featured in the top 10 countries most associated with the Silk Road, i.e., Azerbaijan, Kazakhstan, the Kyrgyz Republic, Mongolia, the People's Republic of China (PRC), Tajikistan, Turkmenistan, and Uzbekistan. Yet, apart from the PRC, none of the CAREC countries are in the top 10 Silk Road countries travelers intend to visit in the next 5 years.

This finding leads to the conclusion that the most fundamental need for the CAREC countries in respect of the international market is building a perception that the countries are, both individually and in combination, destinations that (i) offer a wide range of outstanding tourism experiences with high-quality facilities and standards; (ii) are easy to reach, and travel around in and between; and (iii) provide a safe and secure environment.

The need to develop a coherent and persuasive positive tourism image for the CAREC region as a whole would be an ultimate, long-term goal, possibly best achieved by a strong identification with the Silk Road. In the short to medium term, the focus can most profitably be on creating strong images and brands for subregional partnerships between countries with shared resources and potential to attract visitors on multicountry tours.

\section{B. Accessibility: Air and Land Connections, and Border Regulation and Arrangements}

Limited direct air connections represent a significant obstacle to the development of (i) intraregional tourism between the CAREC countries; and (ii) international tourism to the CAREC countries, both individually and multicountry. While land travel is possible between virtually all of the member countries, it is widely recognized that the current road systems, particularly on routes most appealing to tourists, require upgrading in respect of road quality, buses, and the provision of roadside services.

Visa requirements vary between the different CAREC countries and the source countries of visitors. Some CAREC countries made significant advances in recent times in reducing the entry requirements of foreign visitors, as well as fellow CAREC country visitors. An important current initiative is the proposal to establish a Silk Road visa based on the European Union's Schengen scheme.

While the ultimate goal would be the elimination of visa requirements for travel to and between CAREC countries, the ability to obtain visas-on-arrival or e-visas would be welcomed by the international traveling public and make the region more tourism-friendly. Thus, CAREC 
countries could work with each other to establish entry requirements that are (i) common across all CAREC countries; and (ii) do not necessitate making in-person, or email application ahead of travel.

\section{Tourism Products}

One of the key challenges facing CAREC countries is to broaden the appeal of their tourism product offering and to expand the market segments attracted to CAREC countries beyond the dedicated small-volume adventure tourists. The opportunity exists to diversify the target markets toward the larger-volume segments with interest in learning about natural and cultural heritage while, at the same time, being entertained (i.e., edutainment or infotainment seekers). This necessitates developing appropriate tourism products and experiences (along with upgraded and expanded tourism facility and service standards) that will appeal to the key international and regional market segments: product-market matching principle. Increasing countries' ability to undertake market research and collect and analyze tourism statistics is key for this purpose.

\section{Standards and Service: Human Capacity Development and Facility Certification}

The CAREC countries' tourism policy planning documents recognize the needs to upgrade standards of tourist facilities and increase the supply of trained personnel to internationally accepted and expected standards. Tourism staff in operational contact with tourists require three categories of skills: technical, linguistic, and social. Technical and linguistic skills can be taught through common curricula based on international systems, with qualifications and certification for those who achieve international standards. Training programs can be established in each country using the same curricula and qualification requirements, or organized subregionally with students from two or more countries being taught together.

\section{E. Personal Safety: Medical and Rescue Facilities, and Policing}

As tourism grows, so does the need for facilities to deal with difficulties that might arise concerning tourists' health and well-being. The provision of medical facilities of an adequate scale and standard is an imperative, particularly in areas outside capital cities. To lessen the occurrence of civil and other crimes perpetuated against tourists, it is advisable to provide an emergency call center, police patrols, and a rapid response facility to counter crime in the main centers where tourists congregate.

\section{F. Institutional Arrangements for Tourism}

These various factors cannot be dealt with in isolation: they require coordinated planning and implementation. In examining each of these factors in respect of the CAREC countries, it should be recognized that tourists represent an addition-albeit temporary-to the permanent population of the places they visit and stay in. The tourists have many of the same needsand additional ones-as the destinations' residents. Planning and management of tourism are vitally important and often need strong public sector engagement and investment; while tourism operations are most successfully undertaken by the private sector. 
Institutional arrangements for the private sector to plan, develop, and oversee the operation of the tourism sector necessitates effective public sector leadership and close coordination with private sector businesses. At the same time, attracting tourists to the country necessitates investment in marketing and promotion targeted at the most promising source markets and segments.

Thus, there are two functions: (i) policy, planning, regulation, and overall management; and (ii) marketing and promotion. At the present time, institutional structures in most CAREC countries combine the two functions, possibly inhibiting their effectiveness in developing tourism in line with the markets' needs. On the other hand, in countries where there are few officials with strong tourism skills, resources should be centralized in one organization.

\section{Identification of Regional Tourism Cooperation Opportunities and Recommendations}

Opportunities exist to address the challenges identified through collaboration among CAREC countries in matters such as (i) facilitation of visa and entry requirements, (ii) air connectivity, (iii) tourism product development and service standards, (iv) tourism education and training, (v) foreign investment conditions, and (vi) regional and subregional destination brand and image development. The CAREC countries' national strategies and actions plans recognize the need for external financial and technical assistance in the above areas, indicating a possible role for CAREC development partners.

A series of recommendations have been identified based on (i) national strategies and action plans for tourism development; (ii) inputs received from member countries, development partner, and private sector representatives at the CAREC regional tourism workshop in October 2018 in Tashkent, Uzbekistan; and (iii) examination of best practices and lessons learned from other regional tourism cooperation programs (e.g., Greater Mekong Subregion). Proposed recommendations to pursue on a regional and/or subregional basis under CAREC are summarized in the table below.

\section{Table: Summary of Recommendations}

\begin{tabular}{ll} 
Category & \multicolumn{1}{c}{ Recommendation } \\
$\begin{array}{l}\text { Accessibility and } \\
\text { infrastructure }\end{array}$ & Facilitate common procedures to make visa processes more uniform and tourist- \\
& friendly. \\
- Implement the recommendations of the CAREC Aviation Scoping Study to increase \\
and improve air transport connectivity. \\
- Upgrade land transport facilities on cross-border routes. \\
Tourism products and $\begin{array}{l}\text { - Further exploit the impetus created by ongoing international support for the } \\
\text { experiences }\end{array}$ \\
- development of Silk Road routes for tourism purposes. \\
- Develop appropriate tourism experiences (along with upgraded and expanded facility \\
and service standards) for all markets on a product-market matching principle. \\
Establish and implement across all CAREC countries certification schemes for the \\
different types of tourism facility.
\end{tabular}


Table continued

\begin{tabular}{ll} 
Category & \multicolumn{1}{c}{ Recommendation } \\
Tourism skills and & - Develop tourism education and training courses, both nationally and subregionally, \\
services & with common curricula and qualifications. \\
& - Work with the Silk Road Tourism University (Samarkand) and other institutions to \\
& develop specialist training and encourage other inter-university tourism partnerships. \\
Marketing and & - Establish a CAREC virtual tourism support database to strengthen the collection of \\
promotion & tourism statistics and to share market knowledge. \\
& - Create destination image and branding on a subregional basis under the overall Silk \\
& Road region marketing umbrella. \\
- Strengthen collaboration with the United Nations World Tourism Organization Silk & Road Programme and UNESCO (including market research on UNESCO-designated \\
& sites, and natural and cultural heritage for creating destination image and branding). \\
- & Develop a standard regional investment framework for foreign investors. \\
support & Identify funding support mechanisms to accelerate access improvements, product \\
& development, and marketing of CAREC and its subregions, i.e., sovereign lending, \\
& technical assistance, and nonsovereign lending. \\
- Establish a CAREC tourism expert group to advance tourism work and cooperation and \\
improve public-private coordination and collaboration. \\
institutions
\end{tabular}

CAREC $=$ Central Asia Regional Economic Cooperation; UNESCO = United Nations Educational, Scientific and Cultural Organization.

Source: CAREC Secretariat. 



\section{Introduction}

\subsection{Background to CAREC and Its New Strategy and Objectives}

1. In support of a broader vision endorsed at the 16th Ministerial Conference in October 2017, Central Asia Regional Economic Cooperation (CAREC) expanded its operational priorities to better address the region's development needs and help its member states achieve the 2030 Global Development Agenda through the sustained promotion of regional cooperation and integration. Given that the essence of tourism is to create and foster better dialogue, increased people-to-people exchanges, more economic ties, and increased connectivity throughout the region, its development is an operational priority under CAREC 2030.

2. CAREC will promote a regional approach to sustainable tourism development to maximize economic opportunities while safeguarding ecosystems. Regional initiatives to support the region's large untapped tourism potential will encompass advertising and branding, investing in tourism services and critical infrastructure, jointly developing tourist products, and advocating harmonization and relaxation of visa regimes. ${ }^{1}$

3. Tourism is strongly linked to the achievement of United Nations Sustainable Development Goals (SDGs). The United Nations World Tourism Organization (UNWTO) study, Tourism and Sustainable Development GoalsJourney to $2030,{ }^{2}$ identified three of the 17 SDGs as targets for the tourism sector. These include:

(i) SDG 8: Promote sustained, inclusive, and sustainable economic growth, employment and decent work for all-Decent work and economic growth.

(ii) SDG 12: Ensure sustainable consumption and production patternsResponsible consumption and production.

(iii) SDG 14: Conserve and sustainably use the oceans, seas, and marine resources for sustainable development-Life below water.

\section{CAREC will \\ promote a regional approach to sustainable tourism development to maximize economic opportunities while safeguarding ecosystems.}


4. In addition, tourism can make a strong contribution to SDG 11: Make cities inclusive, safe, resilient, and sustainable. Sustainable tourism is also seen by developing countries as an SDG accelerator, given its direct and multiplying effect on other sectors and industries.

\subsection{The CAREC Region}

5. The 11 countries that make up the CAREC region are at the very center of the world: Afghanistan, Azerbaijan, Georgia, Kazakhstan, the Kyrgyz Republic, Mongolia, Pakistan, the People's Republic of China (PRC), Tajikistan, Turkmenistan, and Uzbekistan. Throughout history, this is the region that has bridged east and west. It has been, and is again becoming, a vibrant trading network, now referred to as the Silk Roads. ${ }^{3}$ Here, empires and cities rose and fell, migrations scattered, and cultures were born. Some of the world's highest mountains, greatest deserts, and largest inland seas are here. Religions have traveled its highways; armies have come and gone. Once again, the world is looking to the cultures, the connecting routes, and the mineral riches of Central Asia: wars and the Great Game have been part of its continuing history. Across its vastness, vibrant cultures and new cities are emerging, and once again, innovation and genius can be seen. Trade and travel are fundamental to this region, and the tourism potential is growing, if challenges can be overcome.

"These are no backwaters, no obscure wastelands. In fact, the bridge between east and west is at the very crossroads of civilization. Far from being at the fringe of global affairs, these countries lie at its very centeras they have done since the beginning of history. Judaism, Christianity, Islam, Buddhism, and Hinduism jostled with each other. It is the cauldron where language groups competed, where Indo-European, Semitic, and Sino-Tibetan tongues wagged alongside those speaking Altaic, Turkic, and Caucasian. This is where great empires rose and fell, where the after-effects of clashes between cultures and rivals were felt thousands of miles away."

\subsection{Purpose and Structure of the Tourism Scoping Study}

6. The scoping study assesses the potential for CAREC to act as a platform to promote a regional approach to tourism development and operation. Its purpose is to identify opportunities for enhancing and expanding cooperation

\footnotetext{
3 The term Die Seidenstrassen ("the Silk Roads") was first used in 1877 by the German geographer, cartographer, and explorer, Baron Ferdinand von Richthofen. P. Frankopan. 2015. The Silk Roads: A New History of the World. Bloomsbury Publishing.

4 P. Frankopan. 2015. The Silk Roads: A New History of the World. London: Bloomsbury Publishing.
} 
among member states in the tourism sector to maximize economic opportunities while avoiding deleterious sociocultural and environmental impacts.

7. Chapter 2 provides a stocktaking analysis of the current state of international tourism, identifying key trends in respect of generating and receiving regions, market segments, and key influences and determinants. Data are drawn from a range of published sources, including the Asian Development Bank (ADB) Data Library, the UNWTO's e-library, the World Travel and Tourism Council (WTTC), the World Economic Forum Tourism Competitiveness Report by country, available ADB and other reports relating to similar bodies (e.g., the Greater Mekong Subregion [GMS] Program), and both government and tourism private sector plans and aspirations. In addition, evidence is gathered from independent country tourism profiles such as TripAdvisor, Lonely Planet, and other online sources, as well as many published travelogues and historical sources. This program of research and analysis has enabled a picture to be developed of tourism demand growth and trends, i.e., tourist sources and destinations, segments and niches, key influences, and future prospects.

8. Chapter 3 contains a strengths, weaknesses, opportunities, threats analysis of tourism development in the CAREC region. This leads into Chapter 4 which outlines how the region's strengths can support increased tourism development, and how the opportunities in the marketplace can be realized.

9. In Chapter 5, the range of obstacles that currently restrict the CAREC region from participating more fully in attracting international tourism and receiving the maximum economic contribution from the tourism sector, are examined. The principal features of countries' existing and planned tourism policies and strategies, and the institutional arrangements for tourism are identified.

10. Chapter 6 examines the existing tourism cooperation initiatives in the CAREC region and presents details of a range of prima facie regional and subregional cooperation and integration opportunities in tourism facilitation, development, and management to maximize the CAREC countries' economic benefits from the sector, while safeguarding ecosystems. A series of tourism collaboration recommendations in the CAREC region is outlined in Chapter 7 , including examples and plans for the expansion of cooperation between groups of CAREC countries, covering areas such as (i) accessibility and infrastructure, (ii) tourism products and experiences, (iii) tourism skills and services, (iv) joint tourism marketing and promotion, ( $v$ ) financing, and ( $\mathrm{vi}$ ) organization and institutions.

11. Lastly, four appendixes cover (i) CAREC member countries' priorities, goals, strategies and targets for their tourism sectors; (ii) the GMS's 21 programs under the five Strategic Directions; (iii) the model of Thailand's system of tourism administration; and (iv) participants' survey results from the CAREC Regional Tourism Workshop in October 2018 in Tashkent, Uzbekistan. 


\section{Current State of Tourism and Future Prospects}

\subsection{Demand Growth and Trends}

12. International tourism continues to show sustained, steady growth above the global economy's level. International tourist arrivals rose $6.8 \%$ in 2017, with an average annual rate of increase of $4.8 \%$ between 2010 and 2017, reaching a level of 1.32 billion and generating receipts of $\$ 1.33$ trillion (up $7.5 \%$ in 2017 , with a 7-year average rate of growth since 2010 of 4.5\%). In contrast, global gross domestic product (GDP) rose $3 \%$ in 2017, a higher rate of growth than most years since $2010 .^{6}$

13. The regions showing the fastest growth in inbound tourism in 2017 are Europe, with an $8.4 \%$ increase in international tourist arrivals, and Asia and the Pacific, with an increase of just under $6 \%$. Of all world regions, Asia and the Pacific, the second most-visited after Europe, has grown the fastest in international tourist arrivals since 2005. It plays a vital role as a source market as well, fuelling much growth in both regional and long-haul destinations. The region produced 335 million international travelers spending $\$ 502$ billion in 2017, 37\% of the world total. ${ }^{7}$ Within Europe, the Central and Eastern Europe subregion recorded a rise in arrivals in 2017 of $4.9 \%$ (and $4.3 \%$ a year between 2010 and 2017). While this subregion contains seven of the CAREC countries, ${ }^{8}$ only data for 2017 for Georgia are included in the UNWTO's data because of the unavailability of information from the other CAREC countries (footnote 7).

14. The rise of international tourism shows few signs of slowing down with arrivals worldwide expected to increase by 3.3\% a year between 2010 and 2030, to reach 1.8 billion by 2030, according to the UNWTO's long-term forecast report Tourism Towards 2030. Between 2010 and 2030, arrivals in emerging destinations ( $+4.4 \%$ a year) are expected to increase at twice the rate of those in advanced economies ( $+2.2 \%$ a year). The market share of emerging economies increased from 30\% in 1980 to $45 \%$ in 2016, and is expected to reach $57 \%$ by 2030, equivalent to over 1 billion international tourist arrivals. ${ }^{9}$

\footnotetext{
UNWTO. 2018. World Tourism Barometer. Volume 16, Issue 3. Madrid.

World Bank Group. 2018. Global Economic Prospects. Washington, DC.

UNWTO and Global Tourism Economy Research Centre. 2018. Asia and the Pacific Grows in Importance for Global Tourism. Madrid

8 Azerbaijan, Georgia, Kazakhstan, the Kyrgyz Republic, Tajikistan, Turkmenistan, and Uzbekistan.

UNWTO. 2018. UNWTO Tourism Highlights 2017. Madrid: World Tourism Organization.
} 
15. Drawing on WTTC reports for eight of the CAREC member countries (Table 1), the next decade will see international tourist arrivals in the CAREC region growing at an average annual rate of $4.9 \%,{ }^{10}$ more than matching the anticipated global expansion of international tourism of $3.3 \%$ a year to 2030 , and 4.4\% a year in emerging economies, as confirmed in the UNWTO's 2017 Tourism Highlights report. ${ }^{11}$ In spite of this, taken in a global context, the aggregate share of CAREC countries (excluding the PRC) is still less than $2 \%$ of world tourism. This illustrates a considerable challenge but, at the same time, an opportunity.

\section{Table 1: Forecasts of International Tourist Arrivals and Visitor Spending in CAREC Countries, 2018-2028}

\begin{tabular}{|c|c|c|c|c|}
\hline CAREC Country & $\begin{array}{c}\text { Forecast } 2018 \\
\text { Tourist Arrivals } \\
\text { '000 }\end{array}$ & $\begin{array}{c}\text { Forecast } 2028 \\
\text { Tourist Arrivals } \\
\text { '000 }\end{array}$ & $\begin{array}{c}\text { \% P.A. } \\
\text { Growth Rate } \\
\text { 2018-2028 in } \\
\text { Tourist Arrivals }\end{array}$ & $\begin{array}{c}\text { \% P.A. } \\
\text { Growth Rate } \\
2018-2028 \\
\text { in Visitor } \\
\text { Spending }\end{array}$ \\
\hline Azerbaijan & 2,125 & 3,235 & 4.3 & 6.1 \\
\hline Georgia & 3,500 & 6,125 & 5.8 & 5.4 \\
\hline Kazakhstan & 6,010 & 8,658 & 3.7 & 3.5 \\
\hline Kyrgyz Republic & 4,088 & 6,130 & 4.1 & 3.5 \\
\hline Mongolia & 474 & 1,021 & 8.0 & 4.0 \\
\hline Pakistan & 1,252 & 2,054 & 5.1 & 6.4 \\
\hline Tajikistan & 218 & 263 & 1.9 & 2.0 \\
\hline Uzbekistan & 2,066 & 4,238 & 7.5 & 6.9 \\
\hline Overall & 19,733 & 31,724 & 4.9 & $\begin{array}{l}\text { Not applicable } \\
\text { as averages } \\
\text { based on local } \\
\text { currencies in } \\
\text { each country }\end{array}$ \\
\hline
\end{tabular}

CAREC $=$ Central Asia Regional Economic Cooperation, P.A. = per annum.

Source: WTTC country reports under Travel and Tourism Economic Impact 2018 series (Afghanistan and Turkmenistan not covered by WTTC). The People's Republic of China not shown.

16. It is acknowledged that, for some countries, WTTC data are not in line with the figures contained in the country presentations at the CAREC Regional Tourism Workshop in Tashkent, Uzbekistan in October 2018. This may be explained by the requirement in the WTTC data for tourists to spend a minimum of 24 hours in the destination country, and visitors staying less than a night failing to qualify.

\footnotetext{
10 WTTC. 2018. Travel and Tourism Economic Impact 2018. Series of country reports for Azerbaijan, Georgia, Kazakhstan, the Kyrgyz Republic, Mongolia, Pakistan, Tajikistan, and Uzbekistan. London.

11 UNWTO. 2017. UNWTO Tourism Highlights 2017. Madrid.
}

Between 2018 and 2028, tourist arrivals in the CAREC region are expected to increase by almost $5.0 \%$ per year. 
Domestic and regional travel represent significant growth opportunities for CAREC countries.

\subsection{Key Influences}

17. Future prospects for the 11 CAREC members will be determined both by external factors such as economic performance and demographic changes in main (and secondary) tourist markets, and by measures which the individual countries within the CAREC group can take-either individually or through association and collaboration with neighbors and other fellow CAREC countries through multicountry initiatives.

18. A fundamental factor in the development of tourism in the CAREC region is the financial ability of the countries' own populations to engage in leisure travel. The aggregate population of the CAREC countries is over 360 million (with over two-thirds of these in Pakistan). In 2017, GDP growth across all CAREC countries (excluding the PRC) averaged 4.5\%-well above the global average for the year. ${ }^{12}$ The consensus view of participants at the October 2018 CAREC Regional Tourism Workshop was there are substantial numbers in CAREC countries with sufficient incomes to engage in leisure travel and, with the increasing access to online and other information about travel possibilities, it is expected that such demand will grow significantly in the short to medium term.

19. Table 2 highlights the large populations of Pakistan, the PRC, and Uzbekistan, and the potential spending power of Azerbaijan, Georgia, Kazakhstan, Mongolia, and Turkmenistan. In addition, the PRC's rising spending power is well recognized. Following the normal pattern of leisure travel expansion akin to a stone dropped into a pond with the ripples spreading gradually outward, the greatest growth on CAREC country populations' leisure travel will be within their home countries and pleasure trips to neighboring countries. Domestic and regional travel represent significant growth opportunities for CAREC countries. In addition to interregional potential, focusing on domestic tourism represents a means by which CAREC countries can instill in their populations the concept of travel for leisure and recreational activities, as well as for nondiscretionary purposes.

20. Tourism development has typically followed the model of commencing with the provision of facilities and experiences for domestic populations to enjoy, before attracting visitors from neighboring and other nearby countries and, eventually, tourists from further afield. Globally, domestic travel spending accounted for $72.7 \%$ of travel and tourism's total contribution to GDP in 2017.13 This model is entirely relevant to CAREC countries, most of which have low international tourism volumes at present. By providing opportunities for tourists from their own country and bordering countries (i.e., other CAREC members and India, the PRC, and the Russian Federation), CAREC members will create both socioeconomic benefits and pave the way for increasing longer-haul foreign tourism in the medium to long term.

\footnotetext{
12 ADB. 2018. Asian Development Outlook 2018 Update. Manila.

13 World Travel and Tourism Council. 2018. Travel and Tourism Economic Impact 2018. London.
} 


\section{Table 2: Populations and Gross Domestic Product Growth in CAREC Member States, 2017}

\begin{tabular}{|c|c|c|c|}
\hline CAREC Country & $\begin{array}{c}\text { Population } 2017 \\
\text { (million) }\end{array}$ & $\begin{array}{c}\text { Per Capita Gross } \\
\text { National Income, } \\
2017 \text { Atlas Method } \\
(\$)\end{array}$ & $\begin{array}{c}\text { Annual Growth Rate } \\
\text { of GDP, } 2017 \\
(\%)\end{array}$ \\
\hline Afghanistan & 35.53 & 570 & 2.5 \\
\hline Azerbaijan & 9.86 & 4,080 & 0.1 \\
\hline Georgia & 3.72 & 3,790 & 5.0 \\
\hline Kazakhstan & 18.04 & 7,890 & 4.1 \\
\hline Kyrgyz Republic & 6.20 & 1,130 & 4.6 \\
\hline Mongolia & 3.07 & 3,290 & 5.3 \\
\hline Pakistan & 197.01 & 1,580 & 5.4 \\
\hline PRC-Xinjiang Uygur & $23.98(2016)$ & - & $3.5(2016)$ \\
\hline PRC_Inner Mongolia & $25.20(2016)$ & - & $1.7(2016)$ \\
\hline Tajikistan & 8.92 & 990 & 7.1 \\
\hline Turkmenistan & 5.76 & 6,650 & 6.5 \\
\hline Uzbekistan & 32.39 & 1,980 & 5.3 \\
\hline
\end{tabular}

CAREC $=$ Central Asia Regional Economic Cooperation, GDP = gross domestic product, $\mathrm{PRC}=$ People's Republic of China.

Sources: World Bank and Asian Development Outlook 2018 Update, except China Statistical Yearbook 2017 for the PRC's Xinjiang Uygur and Inner Mongolia Autonomous Regions. GDP growth for the PRC's Xinjiang Uygur and Inner Mongolia Autonomous Regions relates to gross regional product.

21. International tourist activity is divided into the following categories:

(i) Leisure, recreation, holidays: $53 \%$

(ii) Visits to friends and relatives, health, religion, other personal: 27\%

(iii) Business and professional: 13\%

(iv) Not specified: $7 \%^{14}$

22. These proportions have remained fairly constant over recent decades, as have the determinants of the levels, directions, and types of international travel, i.e., economic factors, demographic change, facilitation (both regulations and transport connectivity), tourism infrastructure and product development, and marketing and promotion.

23. However, the way these influence travel decisions have evolved through the force of information technology (IT). IT has greatly expanded consumer knowledge about destination and experience options, and the ways tourism products and services can be accessed and purchased. IT has also led to

\section{Information technology has greatly expanded consumer knowledge about destination and experience options, and the ways tourism products and services can be accessed and purchased.}

\footnotetext{
14 Statista. 2018. International Inbound Tourism by Purpose of Visit, 2016. Hamburg.
} 
increased sophistication of marketing and promotional methods deployed by destinations and travel operators.

24. In short, there are now more destinations offering a wider range of tourism experiences than ever before; and these destinations market to an increasingly diversified set of tourism market segments and niches. The ready online availability of information on every aspect of travel choice is being exploited by both consumers and travel providers, including destinations.

25. Some key trends identified in the international tourism market can have a direct, positive bearing for a region which has received limited visitation from traditional high-volume and strong growth tourist source markets. These include:

\section{Table 3: Key Trends in International Tourism}

For the Individual Traveler

- The rise of transformative travel: a step in self-fulfillment through travel that goes beyond authentic and experiential travel. It has similar elements to experiential travel, but taken a step further-it is travel motivated and defined by a shift in perspective, self-reflection and development, and a deeper communion with nature and culture. ${ }^{\text {a }}$

- The digital transformation provides consumers with information on every aspect of their travel choices, and allows them to select the travel products and arrangements most directly suited to their preferences and needs.
For the Destination and Travel Operator

- The rise of customer-centricity is delivering increased personalization through the continuing, ever-increasing sophistication of electronic technology. ${ }^{b}$ Travel brands, including destinations, are seeking to deliver a more personalized, end-to-end customer journey to increase consumer loyalty.

- Destination marketing and promotion is directed at the successive stages of the traveler path-from creating awareness, generating interest, transforming interest into desire, provoking action to arrange travel, and responding to feedback after the visit. This aims at encouraging repeat visitation, and positive word-of-mouth to other travelers.

a Vogue. 2017. Why Transformative Travel will be the Travel Trend of 2017. 3 January.

b G. Oates. 2018. The Rise of Customer Centricity is Delivering Personalization at Scale. Skift Megatrends Defining Travel in 2018. New York: Skift.

Source: CAREC Secretariat

26. One consequence of the consumer's search for greater self-fulfillment and the instant and full availability of information is the selection of more offthe-beaten track destinations. The relevance of these changes in the tourist marketplace to the CAREC countries is that those regions not recognized previously as primary tourism destinations, can now position themselves to market segments specifically seeking the types of experience that CAREC countries can offer, based on their individual natural and cultural resources. Appropriate tourism infrastructure, and product and service development and delivery in CAREC countries are needed for this purpose. 
27. Two broad segments of leisure travel of relevance to the CAREC region today are adventure tourism and culture tourism, given the abundant natural and cultural heritage assets of CAREC countries. Other significant segments which CAREC countries can further exploit are city tourism, business tourism (in all its forms), and event tourism.

\subsubsection{Adventure Tourism}

28. The global adventure tourism market was valued at $\$ 444.85$ billion in 2016, and is projected to reach $\$ 1.336$ trillion in 2023, registering an average annual growth rate of $17.4 \%$ between 2017 and 2023. As such, adventure tourism is one of its fastest-growing segments. America and Europe are the two leading regions in this market. The Asia and Pacific region is the fastest-growing destination area for adventure travelers.

29. The adventure tourism market is divided into "hard" and "soft" subsegments. The hard subsegment is associated with physical exertion (and potential risk), and the soft subsegment to experiences such as sightseeing. The soft subsegment dominates the adventure tourism market, as these activities possess moderate to low risks, and consequently attract a large customer base. Moreover, adventure travelers are focusing on less risky adventure activities and are more open to other elements, such as natural environment, learning, and meaningful lifelong experience, which boost the growth of the segment.

30. The growth of adventure tourism is fueled by the desire of travelers to visit undiscovered destinations. For example, Rwanda in Africa has seen dramatic growth in adventure visits to see its wildlife (mountain gorillas); similarly, the mountains of Albania are attracting increasing numbers of adventure tourists. Many CAREC countries fall into the designation "undiscovered" and have high adventure tourism potential, both hard (e.g., trekking on foot, horseback or bicycle riding, climbing, winter sports such as mountaineering, skiing, caving, rafting, and others), and soft (sightseeing of pristine natural sites of lakes, rivers, mountains, and plains). However, the risks involved in adventure travel and, in some instances, unpredictable weather conditions, restrict market growth.

31. In this segment, as in others such as cultural heritage tourism, there is an increase in government initiatives in the form of public-private partnerships to promote adventure tourism. Conversely, the increase in social media is anticipated to provide a strong opportunity for market growth, as Facebook has become the preferred social networking site among travelers to get the best travel deals. ${ }^{15}$

\author{
Adventure tourism \\ and culture tourism \\ are of particular \\ relevance to the \\ CAREC region \\ given the abundant \\ natural and cultural \\ heritage assets of \\ CAREC countries.
}

\footnotetext{
15 Allied Market Research. 2018. Adventure Tourism Market. Portland, Oregon.
} 
The combination of tangible and intangible assets along the ancient Silk Road Route offers potential for increased tourist flows in the CAREC region.

\subsubsection{Culture Tourism}

32. Today, culture tourism is one of the largest and fastest-developing global tourism markets: an estimated four out of 10 tourists choose their destination based on its cultural offering. In a survey of its members, the UNWTO found that almost all respondents included in their definition of cultural tourism both tangible (e.g., national and world heritage sites, monuments, historic places and buildings, cultural routes, and others) and intangible heritage (e.g., crafts, gastronomy, traditional festivals, music, oral traditions, religious or spiritual tourism, and others). Most countries (82\%) also indicated they consider cultural tourism to include contemporary culture (e.g., film, performing arts, design, fashion, new media, and others). One-in-three also cited elements, such as sports, education, health, and shopping as part of cultural tourism. ${ }^{16}$

33. The mix of tangible and intangible heritage with contemporary culture was also seen as imparting uniqueness to the cultural tourism product, which cannot be experienced elsewhere. Tourists are increasingly attracted by intangible factors, such as the atmosphere of a place, its association with famous people, ideas or events -in other words by a place's culture, history, and traditions - rather than simply its tangible assets (footnote 16).

34. In the CAREC region, the historically important Silk Road Route that runs through many CAREC countries, and the combination of tangible assets with the intangible ones of traditional crafts, music, and performance offer potential for increased tourist flows. In addition, circuits combining both natural and cultural heritage features can be further developed, catering to those with a general interest in these aspects of CAREC countries.

\subsubsection{City Tourism}

35. The world's cities are also some of the world's greatest tourism destinations. Tourists are drawn, in growing numbers, to the vibrancy, excitement, and diversity on offer in cities worldwide..$^{7}$ According to the United Nations, the world's urban population grew rapidly from 746 million in 1950 to over 4 billion in 2016 and today, 54.5\% of the world's population lives in urban areas. This proportion is expected to increase further to $60 \%$ by 2050 , with nearly all of the increase concentrated in Asia and Africa. With international tourism arrivals set to rise to 1.8 billion a year by 2030 , and billions more domestic travelers expected, the city share of these arrivals shows particular growth. ${ }^{18}$

36. The growth of city tourism - typically a short break of 1 to 3 days to a single city-accelerated in recent decades with the increasing ease of reaching them due to the expansion of low-cost airlines. While the leading city tourism

\footnotetext{
6 UNWTO. 2018. Tourism and Culture Synergies. Madrid: World Tourism Organization.

17 UNWTO. 2012. Foreword to Global Report on City Tourism. World Tourism Organization. Madrid.

18 World Travel and Tourism Council. 2017. City Travel and Tourism Impact 2017. London.
} 
destinations are in established tourism destination countries, city tourism is a means by which countries not so familiar in tourism markets can be sampled, and their reputation built up as attractive and interesting places to visit.

37. With most of the capital cities of CAREC countries possessing a range of diverse attractions, city tourism represents good potential as a building block for their tourism sectors. Cities such as Baku and Tbilisi have begun to benefit from low-cost carriers, and such carriers in the mass markets of India and the PRC are beginning to extend their reach where regulations allow. Former capitals such as Almaty (Kazakhstan) and Samarkand (Uzbekistan), and other heritage cities can also attract this growing segment. Within city tourism there is the opportunity to develop transit tourism to cities with a good range of air connections, such as Almaty and Tashkent, though the expansion of this form of tourism will be dependent on the facilitation of such visits through easy and speedy border arrangements and the expansion of air connectivity in the CAREC region.

\subsubsection{Business Tourism}

38. For countries not fully established as leisure tourism destinations, the relative importance of visits for business and professional purposes can assume greater significance than the overall global share of $13 \%$ for such visits. Business tourism has a number of strands-trade, investment, and the meetings, incentives, conferences, and incentives (MICE) industry. Each of these are growing in those parts of the world-particularly in Asia and Africa-seeking to develop their international trade, attract inward investment, and cater to regional and international conferences and exhibitions. As Central Asia's importance as a transport corridor is reasserted in the 21st century, business tourism is important.

39. Reflecting the growing integration of CAREC countries in the world's economy, all forms of business tourism-trade, investment, and the MICE industry-can be stimulated as a key part of their tourism development. Georgia is among those leading the way through its 2017 Strategy for MICE Tourism for the operation of the Georgian Convention and Exhibition Bureau. ${ }^{19}$

\subsubsection{Event Tourism}

40. The organization of events with diverse themes continues to be a significant growth sector, e.g., sports, cultural heritage, arts and music, celebration of past achievements, or other events in the history of a place. Such events can have both short- and long-term aims. In the short term, they generate visits from neighboring countries and, depending on the theme of the event, further afield too. In the longer term, they help to establish the reputation of the destination as a tourist destination among those who might have apprehensions about the country's image, but are attracted to the specific event. This creates
CAREC countries can further promote intraregional and foreign visitation through the increased organization of cultural and business-related events.

19 ENITED Business Events. 2017. Consultancy report: Development of a Strategy for MICE Tourism for the Georgian Convention and Exhibition Bureau. Vienna. 
the possibility of a future return visit and positive word-of-mouth among the visitor's circle of friends and contacts.

41. In addition to business-related events, CAREC countries can generate intraregional and foreign visitation through the increased organization of sporting, arts, music, and other forms of cultural heritage events. Recent events in the CAREC countries illustrate this rationale: EXPO 2017 in Astana; the Nomad Games 2018 in the Kyrgyz Republic, which attracted 1,976 competitors from 74 countries, and with the 10,000 seat stadium in Cholpon-Ata full for the opening ceremony; ${ }^{20}$ the Spring Handicraft Fair in March 2018 in Dushanbe to celebrate the Year of Tourism and Folk Crafts Development in Tajikistan, with unique products from artisans representing Afghanistan, Tajikistan, and Uzbekistan; ${ }^{21}$ and the Formula 1 Azerbaijan Grand Prix, which attracted over 90,000 spectators in 2018. ${ }^{22}$

20 New York Times International Edition. Let the Nomad Games Begin! 18 September 2018.

${ }^{21}$ Civil Society Development Association. 2018. A Spring Handicraft Fair was Held in Dushanbe. 13 March 2018.

22 Baku City Circuit. Press Centre. 2018. https://www.bakucitycircuit.com/ (accessed 2 October 2018). 


\section{Strengths, Weaknesses, Opportunities, and Threats Analysis}

42. This chapter presents the strengths, weaknesses, opportunities and threats (SWOT) analysis of tourism development and cooperation in the CAREC region. The SWOT analysis is summarized in Table 4.

\section{Table 4: SWOT Analysis}

\section{Strengths}

- Outstanding range of unspoiled natural resources in all countries

- Steppe, mountain, and desert cultures

- Historic cities and ancient empires

- UNESCO World Heritage Sites close to airports and cities, the foremost being Silk Road-related, and extensive intangible cultural heritage

- Diverse ethnic groups and cultures, both nomadic and settled

- Quality of lodging and other tourism facilities in capital cities

- Political goodwill and support from governments for tourism development

- "New"' destinations for visitors to discover

- CAREC's standing as a neutral and honest broker providing a trusted development platform to advance regional tourism cooperation

- Growing media and travel trade attention to Silk Road tourism
Weaknesses

- Limited air access to, and between, CAREC countries

- Inadequate internal transport infrastructure and facilities on tourist routes, including inter-country ones

- Nonstandardized visa requirements and border entry arrangements

- Long distance and travel time to many CAREC countries from international markets

- Lack of brand awareness and image resulting in little knowledge of CAREC countries and a weak perception of them as tourism destinations

- Limited product development of tourism experiences to appeal to the middle, nonspecialist, market segments

- Language barriers

- Shortages of skilled workers and destination managers

- Limited financing resources

\section{Opportunities}

- Growing international profile of the Silk Road, which links all CAREC members, and ongoing international support for the development of the Silk Road routes for tourism purposes (including proposed series of UNESCO documentaries promoting the rich history and heritage of the region)

- Continued expansion of international tourism, in particular, the fast-growing Asian markets, and the travelers' quest for new experiences and off-the-beaten track destinations

- New infrastructure linkages under development (including under the Belt and Road initiative)

- Continuing rise of information technology enabling prospective travelers to have detailed information on destinations instantly

- Potential role of tourism in the achievement of the Sustainable Development Goals, to which all CAREC countries are signatories

- Regional tourism training initiatives (management and operational)

- Donor support, inward investment, tourism development incentives

\section{Threats}

- Climate change

- Environmental degradation

- Competing destinations

- Economic downturns in primary tourist-generating markets

- Natural and human-created disasters

- Political instability

- Terrorist and civil crimes

CAREC $=$ Central Asia Regional Economic Cooperation; UNESCO = United Nations Educational, Scientific and Cultural Organization Source: CAREC Secretariat. 


\section{Building on Strengths and Capturing Opportunities}

43. The CAREC countries' strengths as tourism destinations arise from their natural and cultural heritage, and historical and built assets: (i) outstanding range of unspoiled natural resources in all countries; (ii) wide variety of cultural and urban tourism assets; (iii) UNESCO World Heritage sites, the foremost being the Silk Road; (iv) diverse ethnic groups and cultures; ( $v$ ) quality of lodging and other tourism facilities in capital cities; and (vi) political goodwill and strong support from governments for tourism development.

44. The growth of, and trends in, international tourism described in Chapter 2 represent a prima facie opportunity for the CAREC countries to develop and sustain their tourism sectors. As a relatively new destination area, the CAREC countries can take advantage of these trends while further exploiting the established reputation of the Silk Road by expanding the range of itineraries based on it.

45. To expand the market segments attracted to CAREC countries beyond the dedicated small-volume adventure tourist, the opportunity exists to diversify the target markets toward the larger-volume segments with interest in learning about natural and cultural heritage, while at the same time being entertained (i.e., edutainment or infotainment seekers). This necessitates developing appropriate tourism experiences (along with upgraded and expanded tourism facility and service standards) for all markets on a product: product-market matching principle (see section 6.5).

46. In capitalizing on the CAREC region's varied natural and cultural heritage strengths, it is vital that these are developed in ways that (i) are in line with the different strata of the tourism market's demands (i.e., domestic, regional, and international; leisure and nondiscretionary; and the various segments within these two categories); and (ii) provide maximum socioeconomic benefits to the host countries while minimizing deleterious sociocultural and environmental impacts, in line with the SDGs. 


\section{Addressing Weaknesses and Challenges}

47. Several challenges currently hinder tourism development and cooperation in the CAREC region. As outlined in Table 4, these include: (i) insufficient air connectivity among CAREC countries and with international markets; (ii) inadequate transport infrastructure, particularly in remote areas; (iii) the still complex visa regimes in many countries and cumbersome border crossing procedures; (iv) limited appeal of countries' tourism products, attracting mainly small-volume market segments; ( $v$ ) low quality of tourism standards; (vi) shortage of skilled workers; and (vii) weak branding and destination image of the region.

48. The success of any destination is a function of a combination of factors, including:

(i) Appeal: brand and image perception among consumers in target markets and segments;

(ii) Accessibility: capacity and quality of transport infrastructure; travel time, frequency, and cost; entry requirements in the form of visas (ease and cost of obtaining); and border arrangements;

(iii) Tourism products: range and quality of things to see and do related to the market segments' interests;

(iv) Standards and service: quality of tourist facilities and service delivery of tourism personnel to internationally expected standards; and

(v) Personal safety: health facilities and policing to provide protection from civil and other crimes.

49. These factors cannot be dealt with in isolation: they require coordinated planning and implementation. In examining each of these factors in respect of the CAREC countries, it should be recognized that tourists represent an addition-albeit temporary-to the permanent population of the places they visit and stay in. The tourists have many of the same needs-and additional ones - as the destinations' residents. Planning and management of tourism are vitally important and often need strong public sector engagement and investment; while tourism operations are most successfully undertaken by the private sector. By definition, close public-private collaboration is vital. 


\subsection{Appeal: Image and Brand Perception}

50. In tourism destination choice, it is important to recognize that prospective visitors cannot "test drive" the destinations they are considering. Their assessment and evaluation that will ultimately determine their selection are a combination of what they learn from media (especially and increasingly social media) and word-of-mouth from travel agents, family, and friends. Not all this information may accurately reflect what the destination has to offer, but "the perception is the reality" when it comes to destination choice.

51. A prime example of how this process presents a challenge for the CAREC countries is the TripAdvisor report on Travel Trends for the Silk Road. ${ }^{23}$ Based on the report's traveler reviews, eight CAREC countries are featured in the top 10 countries most associated with the Silk Road, i.e., Azerbaijan, Kazakhstan, the Kyrgyz Republic, Mongolia, the People's Republic of China (PRC), Tajikistan, Turkmenistan, and Uzbekistan. ${ }^{24}$ Yet, apart from the PRC, none of the CAREC countries are in the top 10 Silk Road countries travelers intend to visit in the next 5 years. This clearly indicates distrust that the CAREC countries can provide

Lack of information on the characteristics of outbound markets hinders the effectiveness of CAREC countries' marketing and promotion activities. good experiences for the intending Silk Road route traveler. Addressing this issue has to be a priority.

52. Many countries that emerged from former Soviet Union in the last decade of the 20th century inherited previous investments in tourism and culture, such as urban and tourist transport infrastructure in Tbilisi (Georgia) and large-scale restorations such as Samarkand's Registan (Uzbekistan), as well as some now-outdated hotels and spas in various countries. Railways that were important for Tsarist troop movements as the Russian empire expanded southward are being upgraded today for trade in all directions.

53. The past has given the region rich and complex resources. Russian remains an important language of communication for much of the region. Until the 20th century, Persian was the language of the courts, diplomacy, and aristocracy for most of the region. Today, there is limited engagement in other international languages of tourism, apart from English in Pakistan and Chinese in the eastern areas. However, a new private sector is emerging with more linguistic skills in this region already rich with so many languages and ethnic groups. Russian and, to a lesser extent, Persian cultural influences remain strong, and the Russian Federation has a significant outbound tourism market to countries where its citizens feel welcome. Turkey is also re-engaging with former Ottoman, and wider Turkic peoples. The big populations of India and the PRC represent multiple segments that might be addressed, but research into them from a CAREC perspective is lacking.

\footnotetext{
23 TripAdvisor. 2016. TripAdvisor Travel Trends for the Silk Road 2016. Published by the UNWTO Silk Road Programme.

24 The two other countries are Iran and Turkey.
} 
54. The presentation by the Georgian National Tourism Administration at the CAREC Regional Tourism Workshop in Tashkent outlined that the key challenge to beaddressed in identifying and delivering well-founded and targeted marketing and promotional strategy and campaigns is the lack of information about the characteristics of outbound markets. Without fuller information on source markets, it is difficult for tourism products to be accurately positioned and targeted at those markets and segments that represent the greatest potential. ${ }^{25}$ This scoping study endorses this finding.

\subsection{Accessibility: Air and Land Connections, and Border Regulations and Arrangements.}

55. There are two aspects to consider: (i) travel to and between the CAREC countries; and (ii) visa and border control procedures.

\subsubsection{Travel to and between the CAREC Countries}

\section{A. Air Access}

56. The CAREC Aviation Scoping Study presents details of the air services between the CAREC countries and airline networks within CAREC. ${ }^{26}$ Key findings are as follows:

(i) Connectivity between CAREC countries is relatively limited by international and regional standards. Currently, less than half of all country pairs within CAREC are served with direct flights.

(ii) The PRC is connected to all 10 other CAREC countries, with Kazakhstan the second best with connections to eight fellow CAREC members, Uzbekistan (six), Azerbaijan and the Kyrgyz Republic (five each) while the other six CAREC countries have links to four or fewer other CAREC countries.

(iii) Frequencies are generally low, making it difficult to travel between CAREC countries where there are direct flights. Of the 110 country pairs within CAREC, only 52 are linked, and two of these have fewer than seven frequencies (i.e., they are not served daily).

(iv) Airlines from the CAREC countries often struggled to maintain regional international routes. Over the last 5 years, service was suspended on eight CAREC country pairs.

25 Georgian National Tourism Administration. 2018. Presentation at CAREC Regional Tourism Workshop_-Promoting Regional Tourism Cooperation under CAREC 2030, Tashkent, Uzbekistan. October 2018. Available at: https://www.carecprogram.org/?event=regional-tourism-workshopoct-2018

${ }^{26}$ CAREC. 2018. Aviation and the Role of CAREC: A Scoping Study, paras. 10-16. Manila.
Intraregional air connectivity remains limited within the CAREC countries. 
(v) CAREC countries are generally better linked to markets outside CAREC. There are approximately 73,000 weekly seats between CAREC countries, including approximately 42,000 between the PRC and other CAREC countries.

(vi) Total weekly capacity among the 10 CAREC countries, excluding the PRC, is close to 1 million seats, but for four of these countries, interCAREC connectivity accounts for less than $10 \%$ of their total international seat capacity.

57. The Aviation Scoping Study did not examine air service connections with major international tourist generating markets. Examination of schedules available through the Skyscanner website indicate that the numbers of direct flights to CAREC destinations are infrequent and limited to Baku (Azerbaijan), Tbilisi (Georgia), Almaty and Astana (Kazakhstan), Tashkent (Uzbekistan), and Karachi and Islamabad (Pakistan) from European centers and, in some cases, from New York, the PRC, and Singapore. The PRC also has direct service to Ulaanbaatar (Mongolia), the PRC's autonomous regions of Inner Mongolia and Xinjiang Uygur, Ashgabat (Turkmenistan), and a once weekly flight to Dushanbe (Tajikistan).

58. While the quickest direct flights from European points are upward of 3.5-5 hours (e.g., to Tbilisi), and to Asian centers, 2-3 hours (Beijing to Ulaanbaatar), connecting flights into the heart of the CAREC region to destinations, such as Dushanbe (Tajikistan), can take over 8-10 hours, or longer, both from European and Asian centers. This is a disincentive for both leisure and business tourism.

59. Limited direct air connections represent a significant obstacle to the development of (i) intraregional tourism between the CAREC countries; and (ii) international tourism to the CAREC countries, both individually and on a multicountry basis. The conclusion of the aviation scoping study is pertinent in considering the growth of tourism and regional cooperation in tourism:

"Regional tourism is a particularly promising segment and goes together with improved connectivity within CAREC. Most tourists visiting CAREC countries are from outside the region. CAREC member countries would be able to attract more visitors from other CAREC countries if air connectivity improved, taxes were reduced, and visa requirements were eased. CAREC countries would also benefit if more outside visitors traveled around the region, stopping in multiple CAREC countries."

60. The overall conclusion of the aviation scoping study is that: "A safe, reliable, and efficient aviation sector can be a pivotal component in driving economic growth. A more open CAREC aviation market will reduce transport costs and travel times, leading to direct benefits to governments, the private sector, and consumers." 


\section{B. Land Transport}

61. The road and rail connections between the CAREC countries are already used in a number of existing multicountry tour programs. Indeed, land travel is possible between virtually all of the member countries. Nonetheless, there is wide recognition that the current systems, particularly on routes most appealing to tourists, require upgrading in terms of road quality, buses, and the provision of roadside services. Car rental for self-drive cross-border tourism is a potential growth segment, but without easement of land travel border arrangements and service areas along popular routes, this potential will not be realized.

62. These shortcomings are noted in several of the tourism policy and planning documents reviewed. Investment in upgraded rail connections in CAREC countries is taking place with support from international donors. However, freight movement has been the priority.

\subsubsection{Visa and Border Control Procedures}

\section{A. Visa Requirements}

63. Each CAREC member country uses its own systems of visa and border entry arrangements for foreign visitors. Visa requirements vary between the different CAREC countries and the source countries of visitors. Many CAREC countries have made significant advances in recent times in reducing the entry requirements of foreign visitors and fellow CAREC country visitors. The most recent examples include Uzbekistan's 30-day visa waiver to 45 countries (starting from 1 February 2019) and Pakistan's plans to ease visa restrictions for visitors from 55 countries.

64. Visa requirements for fellow CAREC country visitors. In countries where visa-free entry is granted, it is normally to visitors from former Soviet countries. For four CAREC countries, all visitors from fellow CAREC countries require visas (Afghanistan, Pakistan, the PRC, and Turkmenistan). The present arrangements for visa entry between CAREC countries are summarized in Table 5 .

65. International market visa requirements. While visa regimes change and are sometimes unclear, based on an analysis of principal international tourist generating markets, a complicated picture emerges. The analysis is based on a sample list of countries from the various regions of the world: European Union (EU, e.g., Germany), North America (e.g., United States), Central and South America (e.g., Brazil), Africa (e.g., South Africa), Middle East (e.g., United Arab Emirates [UAE]), Southeast Asia (e.g., Singapore), Northeast Asia (e.g., Japan), and Oceania (e.g., Australia). The summary table below (Table 6) is for illustrative purposes and is based on the sample countries only.

66. Where visas can be obtained online (e-visa), travelers have minimal problems, but where attendance is required at an embassy or consulate, this
Complex visa procedures and entry requirements constrain tourism development in the region. 
Table 5: Visa-Entry Arrangements between CAREC Countries

\begin{tabular}{|l|c|c|c|c|c|c|c|c|c|c|c|}
\multicolumn{1}{r}{$\begin{array}{c}\text { Traveling } \\
\text { from }\end{array}$} & & & & & & & & & \\
Traveling to & AFG & AZE & PRC & GEO & KAZ & KGZ & MON & PAK & TAJ & TKM & UZB \\
\hline AFG & & C & C & C & C & C & C & C & C & C & C \\
\hline AZE & C & & A/B & F & F & F & B & B & F & B & F \\
\hline PRC & C & C & & C & C & C & C & C & C & C & C \\
\hline GEO & B & F & B & & F & F & B & B & F & F & F \\
\hline KAZ & C & F & C & F & & F & F & C & F & C & F \\
\hline KGZ & B & F & B & F & F & & F & B & F & B & F \\
\hline MON & C & C & C & C & F & F & & C & C & C & C \\
\hline PAK & C & C & C & C & C & C & C & & C & C & C \\
\hline TAJ & B & F & B & F & F & F & A/B & B & & A/B & F \\
\hline TKM & C & C & C & C & C & C & C & C & C & & C \\
\hline UZB & B & F & B & F & F & F & B & B & F & B & \\
\hline
\end{tabular}

$A=$ visa on arrival, $B=$ eligible for e-visa, $C=$ visa required prior to travel, $F=$ visa-free. All results relate to ordinary passport holders. AFG $=$ Afghanistan, AZE $=$ Azerbaijan, CAREC $=$ Central Asia Regional Economic Cooperation, GEO = Georgia, KAZ = Kazakhstan, KGZ = Kyrgyz Republic, MON = Mongolia, PAK = Pakistan, $\mathrm{PRC}=$ People's Republic of China, $\mathrm{TAJ}=$ Tajikistan, $\mathrm{TKM}=$ Turkmenistan, $\mathrm{UZB}=$ Uzbekistan.

Source: Passport Index. 2018. Compare passports. http://www.passportindex.org (accessed 23 November 2018).

\section{Table 6: Visa-Entry Requirements for International Markets in CAREC Countries}

\begin{tabular}{|c|c|c|c|c|c|c|c|c|c|}
\hline $\begin{array}{l}\text { Traveling } \\
\text { from }\end{array}$ & GER & USA & BRA & ZAF & UAE & JPN & SIN & IND & AUS \\
\hline AFG & C & C & C & C & C & C & C & C & C \\
\hline AZE & B & B & B & B & $A / B$ & $\mathrm{~A} / \mathrm{B}$ & $A / B$ & B & B \\
\hline PRC & C & C & C & C & $\mathrm{F}$ & $\mathrm{F}$ & $\mathrm{F}$ & C & C \\
\hline GEO & $\mathrm{F}$ & $\mathrm{F}$ & $\mathrm{F}$ & $\mathrm{F}$ & $\mathrm{F}$ & $\mathrm{F}$ & $\mathrm{F}$ & B & $\mathrm{F}$ \\
\hline KAZ & $\mathrm{F}$ & $\mathrm{F}$ & $\mathrm{F}$ & C & $\mathrm{F}$ & $\mathrm{F}$ & $\mathrm{F}$ & C & $\mathrm{F}$ \\
\hline KGZ & $\mathrm{F}$ & $\mathrm{F}$ & $\mathrm{A} / \mathrm{B}$ & $\mathrm{A} / \mathrm{B}$ & $\mathrm{F}$ & $\mathrm{F}$ & $\mathrm{F}$ & B & $\mathrm{F}$ \\
\hline MON & $\mathrm{F}$ & $\mathrm{F}$ & $\mathrm{F}$ & C & C & $\mathrm{F}$ & $F$ & C & C \\
\hline PAK & C & C & C & C & C & C & C & C & C \\
\hline TAJ & $\mathrm{A} / \mathrm{B}$ & $A / B$ & $\mathrm{~A} / \mathrm{B}$ & $\mathrm{A} / \mathrm{B}$ & $\mathrm{A} / \mathrm{B}$ & $A / B$ & $\mathrm{~A} / \mathrm{B}$ & B & $\mathrm{A} / \mathrm{B}$ \\
\hline TKM & C & C & C & C & C & C & $C$ & C & C \\
\hline UZB & B & B & B & B & B & $\mathrm{F}$ & $\mathrm{F}$ & B & B \\
\hline
\end{tabular}

$A=$ visa on arrival, $B=$ eligible for e-visa, $C=$ visa required prior to travel, $F=$ visa-free. All results relate to ordinary passport holders. AFG = Afghanistan, $\mathrm{AUS}=$ Australia, $\mathrm{AZE}=$ Azerbaijan, $\mathrm{BRA}=$ Brazil, $\mathrm{CAREC}=$ Central Asia Regional Economic Cooperation, GEO = Georgia, GER = Germany, IND = India, JPN = Japan, KAZ = Kazakhstan, KGZ = Kyrgyz Republic, MON = Mongolia, PAK= Pakistan, PRC= People's Republic of China, $\mathrm{SIN}=$ Singapore, TAJ = Tajikistan, TKM = Turkmenistan, UAE = United Arab Emirates, USA = United States of America, UZB = Uzbekistan, ZAF = South Africa, .

Source: Passport Index. 2018. Compare passports. http://www.passportindex.org (accessed 23 November 2018). 
can act as a significant deterrent, as can visa fees which vary significantly. Nonetheless, for foreign visitors planning to travel to more than one country, unless the countries to be visited have no visa requirements, or visas can be granted on arrival, the task of obtaining the necessary entry permits is daunting. While it is easier for CAREC country residents seeking to travel to more than one country within the CAREC family, there are difficulties associated with travel to Afghanistan, Pakistan, the PRC, and Turkmenistan.

67. The UNWTO's studies on visa openness advocate visa reciprocity between members within regional blocs. It finds that the benefits of visa facilitation are not strictly limited to members within economic and regional blocs, but also affect the relationships with nonmembers. As such, visa facilitation may be a catalyst for strategic policy formulation and improvements that maximize the positive impacts, not only for the population of these blocs, but also trigger improved visa policies for visitors. ${ }^{27}$

68. The UNWTO's Visa Openness Report 2018 shows that the regions with greatest visa reciprocity are the EU's Schengen area, the Economic Community of West African States, the Association of Southeast Asian Nations (ASEAN), and Gulf Cooperation Council countries. None of the CAREC countries are listed among the world's most open destinations in 2018. ${ }^{28}$

69. Proposed Silk Road visa. A major new initiative announced at the March 2018 Summit of Heads of State of Central Asia, and led by the governments of Kazakhstan and Uzbekistan, was the proposal for a Silk Road Visa, modeled along the lines of the EU's Schengen visa arrangement. The Silk Road visa would permit all countries located along the Silk Road to be visited on a single tourist visa. The advantages of such a combined visa are claimed to be (i) reduction of time for visa issuance to 10-14 days, facilitating multicountry visitation; (ii) clear and standard procedures for obtaining the visa; (iii) improvement in the safety of travelers through granting Silk Road visa tourists a special status; (iv) facilitation of the organization of travel groups; and (v) support to the development of new interregional routes involving two or more countries. ${ }^{29}$

\section{B. Border Arrangements}

70. The system of border controls at many airports - and at almost all land border crossings - frequently involves lengthy queues and processing times that are not in line with international standards and foreign visitors' expectations. Again, this is an issue acknowledged in CAREC countries' tourism policy planning documents with steps identified to improve the situation, including upgraded (or purpose-built) facilities and infrastructure for immigration and customs,

27 UNWTO. 2016. Visa Openness Report 2015. Madrid: World Tourism Organization.

28 UNWTO. 2018. Visa Openness Report 2018. Madrid: World Tourism Organization.

29 Information on the introduction of the visa regime "Silk Road" provided by Kazakhstan to the CAREC Secretariat. 
increased use of electric technology, and separate lines for inter-CAREC and foreign visitors.

71. Taking all aspects of entry to CAREC countries, the recommendations of the aviation scoping study are fully endorsed: (i) CAREC should consider introducing a uniform visa-free policy to facilitate travel between member countries; and (ii) CAREC countries should work at reducing processing time at immigration and customs, particularly for visitors from other CAREC countries. However, these improvements should be extended to visitors from international markets too, so the experience in entering and departing from CAREC countries is not out of line with procedures in other countries seeking to attract tourists from outside the CAREC region.

\subsection{Tourism Products}

72. The first three pages of the Google search ${ }^{30}$ for tours in the different CAREC countries reveal that the present range of tours offered from European source countries to CAREC countries is a mixture of (i) tours following sections of the Silk Road, (ii) nature-based tours-mainly hard adventure (i.e., trekking and winter sports); (iii) combined cultural heritage and nature sightseeing tours; and (iv) city tours. Tour operators also make arrangements for business tourists to CAREC countries.

73. Google search identified that tour programs are currently offered from Europe to all CAREC member countries, even those for which security arrangements have to be provided, such as the Afghan Explorer Tour offered by Wild Frontiers Travel, Responsible Travel, and Afghan Logistics Tours. The following examples (Table 7) are presented as being indicative of the range

\section{Table 7: Multicountry Tour Programs Offered from Europe to CAREC Countries}

\begin{tabular}{|c|c|c|c|}
\hline \multicolumn{4}{|c|}{ Silk Road and Other Historical Tours } \\
\hline Tour Operator & Tour Name & Countries & No. of Days \\
\hline Responsible Travel & Turkey to Mongolia Silk Road Route & $\begin{array}{l}\text { - AZE, GEO, KGZ, MON, PRC, } \\
\text { TKM, and UZB }\end{array}$ & 120 \\
\hline Kalpak Travel & Silk Road Tour of Central Asia & - KAZ, KGZ, TAJ, and UZB & 15 \\
\hline Mircorp & Various tours & - KAZ, KGZ, TAJ, TKM, and UZB & $14-16$ \\
\hline \multirow[t]{4}{*}{ Advantour } & Silk Road tours & $\begin{array}{l}\text { - Xinjiang Uygur (PRC), KAZ, and } \\
\text { KGZ }\end{array}$ & 12 \\
\hline & & - Xinjiang Uygur (PRC) and KGZ & 10 \\
\hline & & $\begin{array}{l}\text { - KGZ, Xinjiang Uygur (PRC), and } \\
\text { UZB }\end{array}$ & $12-19$ \\
\hline & & $\begin{array}{l}\text { - KAZ and Xinjiang Uygur (PRC), } \\
\text { TAJ, TKM, UZB }\end{array}$ & 19 \\
\hline
\end{tabular}

continued on next page

30 It should be noted that Google search can introduce bias based on the reviewer's location and interests. 
Table 7 continued

\begin{tabular}{|c|c|c|c|}
\hline \multicolumn{4}{|c|}{ Silk Road and Other Historical Tours } \\
\hline Tour Operator & Tour Name & Countries & No. of Days \\
\hline $\begin{array}{l}\text { Central Asia } \\
\text { Adventures }\end{array}$ & Marco Polo Road & $\begin{array}{l}\text { - KGZ, Xinjiang Uygur (PRC), and } \\
\text { TAJ }\end{array}$ & 24 \\
\hline Travel and Culture & Karakorum Tour & - Xinjiang Uygur (PRC) and PAK & 14 \\
\hline Travel and Culture & Pakistan China Silk Road tour & - PAK and PRC & $\begin{array}{l}\text { Various tour } \\
\text { durations }\end{array}$ \\
\hline Native Eye & Silk Road Explorer & - TAJ and TKM & 16 \\
\hline Regent Holidays & Silk Road Empires Tour & - TKM and UZB & 15 \\
\hline Silk Road Explore & Great Silk Road & $\begin{array}{l}\text { - Xi'an (PRC), Xinjiang Uygur } \\
\text { (PRC), Tehran (Iran), KGZ, TKM, } \\
\text { and UZB }\end{array}$ & 35 \\
\hline \multicolumn{4}{|l|}{ Adventure Tours } \\
\hline Tour Operator & Tour Name & Countries & No. of Days \\
\hline Wild Frontiers Travel & Wakhan Pamir Adventure Tour & $\begin{array}{l}\text { - AFG and TAJ (can be extended } \\
\text { to UZB) }\end{array}$ & 20 \\
\hline Hinterland Travel & $\begin{array}{l}\text { Uzbekistan and Lapis mines of } \\
\text { Afghanistan }\end{array}$ & $\begin{array}{l}\text { - UZB and AFG, with possibility } \\
\text { of extension to PAK (security } \\
\text { permitting) }\end{array}$ & $15-16$ \\
\hline Kalpak Travel & $\begin{array}{l}\text { Multi-active tour (foot, mountain } \\
\text { bike, horseback) }\end{array}$ & - KAZ and KGZ & 15 \\
\hline Native Eye Travel & Altai Explorer tour & $\begin{array}{l}\text { - KAZ, MON, and the Russian } \\
\text { Federation }\end{array}$ & 25 \\
\hline $\begin{array}{l}\text { Central Asia } \\
\text { Adventures }\end{array}$ & $\begin{array}{l}\text { Muztag Ata Peak, Kun Lun } \\
\text { Expedition }\end{array}$ & - KGZ and Xinjiang Uygur (PRC) & 25 \\
\hline KE Adventure Travel & Ultimate Fann Mountains Trek & - TAJ and UZB & 15 \\
\hline Intrepid Travel & Overland tours & - Iran with TKM and UZB & 29 \\
\hline \multicolumn{4}{|c|}{ Combined Historical, Cultural, and Natural Heritage Tours } \\
\hline Tour Operator & Tour Name & Countries & No. of Days \\
\hline Advantour, Evaneos & Best of "Central Asia" & - KAZ, KGZ, TAJ, TKM, and UZB & $8-27$ \\
\hline Amicus & Wonders of Asia & - PRC and MON & $13-15$ \\
\hline Advantour & Silk Road Group Tours & $\begin{array}{l}\text { - Xinjiang Uygur (PRC), KGZ, and } \\
\text { UZB }\end{array}$ & $9-14$ \\
\hline Intrepid Travel & Pakistan China Complete Tour & - PAK and PRC & 32 \\
\hline KE Adventure Travel & $\begin{array}{l}\text { Mountains and Marvels of Central } \\
\text { Asia }\end{array}$ & $\begin{array}{l}\text { - Two or more of KGZ, TAJ, TKM, } \\
\text { and UZB }\end{array}$ & 15 \\
\hline \multicolumn{4}{|l|}{ Events Tours } \\
\hline Tour Operator & Tour Name & Countries & No. of Days \\
\hline Central Asia Travel & Nowruz Oriental New Year holiday & - TKM and UZB & 10 \\
\hline City Tours & & & \\
\hline
\end{tabular}

Multicountry city tours are not offered. Single center short duration city tours are offered to Baku (AZE) and Astana and Almaty (KAZ).

$\mathrm{AFG}=$ Afghanistan, $\mathrm{AZE}=$ Azerbaijan, $\mathrm{CAREC}=$ Central Asia Regional Economic Cooperation, $\mathrm{GEO}=\mathrm{Georgia}, \mathrm{KAZ}=$ Kazakhstan, KGZ = Kyrgyz Republic, MON = Mongolia, PAK = Pakistan, PRC = People's Republic of China, TAJ = Tajikistan, TKM = Turkmenistan, UZB= Uzbekistan.

Source: websites of tour operators. 
One of the key challenges facing CAREC countries is to broaden the appeal of their tourism product offering. and type of tour available-and relate only to European source markets. It is acknowledged that the interests and requirements of Asian touristspredominantly from Japan, the Republic of Korea, and the PRC-and of the Russian Federation's tourists, will differ in many respects from the interests and requirements of tourists from Europe and other international markets, so a similar analysis to that below will be needed to fully understand the potential from these markets and how to realize it.

74. This partial listing indicates that there are already a significant range of multicountry tours available that link the different CAREC countries' major tourist attractions. At the very least, this indicates both: (i) the private sector's interest and commitment to develop and market tour programs to combinations of the CAREC countries; and (ii) the CAREC region's market appeal, albeit to the most adventurous and committed end of the tourist market.

75. The role of tour operators is very important. They can act as pioneers in opening up tourism to off-the-beaten-track destinations for the category of traveler. One example is Advantour that states it has policies of

(i) collaborating closely with family-owned hotels, guesthouses, and "national houses" (where locals provide meals to visitors in their homes);

(ii) identifying off-the-beaten-track destinations and communities where a flow of tourists will improve the economic situation for many households; and

(iii) investing in the long-term development of off-the-beaten-track destinations by providing information on the operator's website. ${ }^{31}$

76. One of the key challenges facing CAREC countries is to broaden the appeal of their tourism product offering. The tourism interest-demand pyramid in the figure illustrates the relationship between the tourist's level of interest in a form of special interest tourism (e.g., nature-based tourism, though the same principles apply to most forms of special interest tourism), and the scale of the market demand. The greater the tourist's dedication to the subject (wanting to see and experience the facets of the subject of interest in detail), the smaller is the market size. At the extremes are a small number of people with a deep interest in the subject, while at the other extreme, the mass market has little or no interest in the special interest form of tourism.

77. As illustrated through the examples in Table 7, the present range of tours offered in CAREC countries caters to two broad market segments: (i) those with a deep interest in and commitment to hard adventure experiences; and (ii) those with a fascination for the Silk Road, and associated historic and cultural heritage features.

\footnotetext{
31 Advantour. Silk Road Operator. Presentation at CAREC Regional Workshop-Promoting Regional Tourism Cooperation under CAREC 2030, Tashkent, Uzbekistan. October 2018. Available at: https:// www.carecprogram.org/?event=regional-tourism-workshop-oct-2018
} 
Figure: Model of Nature-Based Tourism Demand

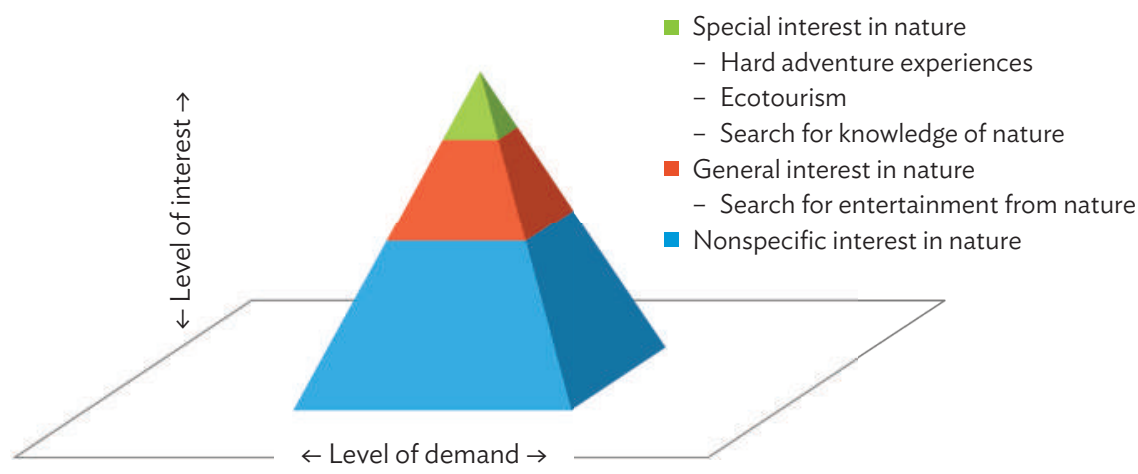

Source: Author's own figure.

78. The hard adventure segment is drawn from the upper part of the Tourism Demand Pyramid in the figure. These tourists are prepared for intensive physical experiences to fulfill their goal, and are prepared to accept rudimentary facilities and creature comforts. The numbers of such travelers is relatively small, as illustrated in the figure. Silk Road enthusiasts occupy both the top part of the Tourism Demand Model but also, in increasing numbers, the central parts where their expectation is for the features of the Silk Road to be presented in a way that combines fact with entertainment. The volume of these travelers is quite substantial, and they expect good standard facilities and services.

79. Indeed, the TripAdvisor survey finding in section 5.1. that none of the CAREC countries are in the top 10 Silk Road countries travelers intend to visit in the next 5 years, is an indication that they do not feel the experiences provided would be sufficiently interesting to make a visit (footnote 23). Of course, this may have more to do with their negative perception of the CAREC countries as tourism destinations than with the products and experiences provided.

80. Thus, the challenge facing CAREC countries is to realize the potential in the central parts of the pyramid through (i) product improvements; (ii) the creation of positive perceptions and image development; and (iii) increased accessibility, and facility and service improvements-but doing so without deleterious impacts on the environmental and cultural heritage features that attract visitors.

\subsection{Standards and Service: Human Capacity Development and Facility Certification}

81. To attract visitors from the central strata of demand (i.e., those with a general interest in the attractions in the destination they choose to visit, but wanting a set of experiences based on informed and entertaining interpretations
An upgrading of standards is needed across the region to attract tourists, both in respect of tourist facilities and services. 
of these features), an upgrading of standards is needed across the CAREC region, both in respect of tourist facilities (e.g., accommodations and tour operations) and services.

82. The nine tourism policy planning documents submitted to the CAREC Secretariat recognize the need to invest in education and training for the tourism sector, and most stipulate the need to meet international standards in facility provision (see Appendix 1 for the summary of tourism priorities, strategies, and targets of CAREC countries). However, there are few stated instances where countries intend to work with each other to establish common service standards and certification schemes by which the international travel trade and prospective tourists can get reassurance.

\subsection{Safety and Security: Medical and Rescue Facilities, and Policing}

83. As tourism grows, so does the need for facilities to cater to not just their demands, but also to deal with difficulties that might arise concerning their health and well-being. The provision of medical facilities of an adequate scale and standard is an imperative. There appears to be little problem with medical facilities within the capital cities of CAREC countries. However, travel to other areas, especially in the countryside and mountainous areas when using land transport, trekking, climbing, and others, creates a higher level of risk and the need for efficient rescue and medical facilities in the event of accidents, illness, and similar emergencies. Again, these needs are acknowledged in many of the CAREC countries' tourism policy and strategic planning documents.

84. The second aspect of visitors' safety relates to civil and other crimes perpetuated against them. While every possibility cannot be covered, it is necessary to provide an emergency call center, police patrols, and a rapid response facility to counter crime in the main centers where tourists congregate. Again, this issue is recognized in a number of CAREC countries and actions incorporated in their tourism plans (e.g., the Kyrgyz Republic plans to create a resort police pilot project). ${ }^{32}$

\subsection{Institutional Arrangements for Tourism}

85. Given the importance of farsighted, comprehensive, and holistic policies, strategies, and plans for the tourism sector, the roles of the institutional bodies responsible for tourism in CAREC countries need to be examined prior to consideration of the various factors outlined above. Institutional arrangements to plan, develop, and oversee the operation of the tourism sector by the private

\footnotetext{
32 Government of the Kyrgyz Republic. 2016. Tourism Development Program of the Kyrgyz Republic until 2020. Action under Objective 9. Bishkek.
} 
sector necessitates effective public sector leadership and close coordination with private sector businesses. At the same time, attracting tourists to the country necessitates investment in marketing and promotion targeted at the most promising source markets and segments. Thus, the two functions are (i) policy, planning, regulation, and overall management; and (ii) marketing and promotion.

86. Each of the CAREC countries has established tourism as a function within government, variously treated as follows: a separate agency (Azerbaijan), a national tourism administration (Georgia), or development corporation (Pakistan); or combined with others such as Information and Culture (Afghanistan, the Kyrgyz Republic); Environment (Mongolia); Culture and Sport (Kazakhstan); Foreign Affairs (Turkmenistan); Education, and Health, Physical Culture, and Sport (Uzbekistan). Separate state tourism committees have been established in some countries to promote development and marketing (e.g., Kazakhstan, Tajikistan, Turkmenistan, and Uzbekistan). In the PRC, provincial tourism authorities report to the Ministry of Culture and Tourism. ${ }^{33}$

87. In Kazakhstan, a new state-owned company, Kazakh Tourism, is tasked with developing tourism products and coordinating the measures to create an industry-friendly environment, including institutional changes and regionspecific goals of reconstructing popular resort zones and highways. It is to address issues such as visa and migration regimes, lack of qualified personnel, and creating competitive tourist goods and services. The focus will be on "soft" infrastructure, where funding requirements are limited but which can provide a quick return on investment. This will entail a wider use of mass media, including television, the internet, and social networks in an effort to shape the country's international tourist image-a brand of a new destination. ${ }^{34}$

88. Despite being a state-owned company, it needs more skills, systems, clearly defined institutional instruments such as attributions and scope of activities, regulatory powers over the sector, delegation of powers to represent the government before the private sector in concessions or other public-private partnership mechanisms, adequate funding, management tools, and adequate policy instruments to enable the support to public entities and private sector in their investment requirements..$^{35}$

89. In establishing institutional arrangements for tourism planning, development, and management, it is imperative that the public and private sectors work in unison. Various models exist that seek to achieve this united approach. These are explored in the ADB 2016 report, Strategic Directions for the Almaty-Bishkek Corridor Initiative, ${ }^{36}$ the conclusion being that the approach

33 On 19 March 2018, the PRC announced that the Ministry of Culture and China National Tourism Administration have been merged to create the Ministry of Culture and Tourism.

${ }^{34}$ Eurasian Press Agency. 2018. Kazakhstan Seeks Ways to Bolster Tourism. http://eurasiatx.com/ kazakhstan-seeks-ways-bolster-tourism/. 15 January 2018.

35 ADB CAREC. 2018. Almaty-Bishkek Economic Corridor Joint Tourism Development Proposal. Manila.

36 ADB CAREC. 2016. Strategic Directions for the Almaty-Bishkek Corridor Initiative. Manila. Appendix 9: Good Practices of Tourism Governance in UK, Japan, Thailand, and the Republic of Korea.
In establishing institutional arrangements for tourism planning, development, and management, it is imperative that the public and private sectors work in unison. 
adopted in Thailand (Appendix 3) offers significant benefits for the two countries of Kazakhstan and the Kyrgyz Republic, where it was found that the central administrative organizations in both countries were performing both the policy, planning, regulation, and management, and marketing and promotion functions. The report concluded that, by separating the functions, enabling the private sector to play a role in determining and implementing marketing and promotion strategy, the organizations could operate more efficiently and effectively (footnote 36 ).

90. In countries where there are few officials with strong tourism skills, resources should be centralized in one organization. Currently, institutional structures in most CAREC countries combine the two functions in one organization, but in the future, this may inhibit their effectiveness in developing tourism that is in line with the markets' needs and expectations, and attracting tourists to whom the countries' product offerings have the most appeal. 


\section{Identification of Regional Tourism Cooperation Opportunities}

\subsection{National Policy and Planning Strategies and Action Plans}

91. Policy and planning strategy documents were prepared and submitted to the CAREC Secretariat for nine CAREC members (Appendix 1). At the time of drafting this scoping study, Afghanistan and Turkmenistan had not submitted their official tourism policy and plan documents. It is acknowledged that Turkmenistan is currently in the process of preparing a national tourism development program. In addition to national level tourism policies, strategies, and plans, there are various initiatives by CAREC member countries working with the UNWTO Silk Road Programme. ${ }^{37}$

92. These official documents indicate that countries recognize their shortcomings in key areas of provision essential for the operation of a tourism sector generating maximum economic benefits; and they seek to address these through a range of actions outlined in their policy statements and strategic plans. Actions are identified in all these documents to address the individual country's needs in (i) marketing and promotion - brand and image development, (ii) transport and facility infrastructure provision, (iii) air connectivity to and between the CAREC countries, (iv) simplification and acceleration of visa clearance and border arrangements, (v) tourism product development, (vi) improved operational and service standards to international levels, and (vii) visitor safety.

93. In virtually all cases, it is recognized that the programs of activities to implement the various actions identified will require external financial and technical assistance, indicating a possible role for CAREC and other agencies providing technical and financial assistance.
CAREC countries' tourism strategies and action plans recognize the need to mobilize more resources, including external financial and technical assistance.

\footnotetext{
37 UNWTO. 2016. Silk Road Action Plan 2016/2017. Madrid: World Tourism Organization.
} 


\subsection{Existing Tourism Cooperation in the CAREC Region and Best Practices from Other Regions}

94. While individual CAREC countries possess outstanding resources for the development of substantive tourism sectors, their potential can be significantly increased if access was made easier and visitors could combine their trips to two or more countries. It is important to acknowledge that cooperation does exist in respect of tourism in the CAREC countries-typically between subgroups or with neighboring countries. Silk Road initiatives (both the PRC's 21st century version and UNWTO's Silk Road Programme), as well as the Silk Road visa initiative (para. 69), are major coalescing influences on those CAREC countries through which its different routes run, as evidenced by the International Forum of the Silk Road Member Countries in Kazakhstan in September 2018.

95. In addition, a number of other cross-border tourism-related initiatives are already taking place or are planned in the short or medium term. Examples include the following:

(i) Agreement for visa-free travel between Tajikistan and Uzbekistan (March 2018), and the tour operators of the two countries entering into a memorandum of cooperation on joint promotion of the cross-border route along the Great Silk Road.

(ii) Bilateral agreements of the Government of Tajikistan with six CAREC countries, with a similar agreement being drafted for Georgia. The aims of these agreements are: "expanding tourist exchange between the countries in order to get experience in living, history, and culture of the nations. These agreements create a basis for cooperation between authorized state tourism agencies and travel operators in order to increase the flow of tourists, and also promote shared tourist routes and brands through holding international conferences, forums, seminars, exhibitions, and fairs, as well as advertisement and media publications." 38

(iii) Program on Mutual Cooperation for 2018-2019 covering a number of economic sectors including tourism between the governments of Kazakhstan, the Kyrgyz Republic, Tajikistan, Turkmenistan, and Uzbekistan. ${ }^{39}$

38 A. Ibragimova, Tourism Development Committee of the Government of Tajikistan. Speech at CAREC Regional Workshop-Promoting Regional Tourism Cooperation under CAREC 2030, Tashkent, Uzbekistan. October 2018. https://www.carecprogram.org/?event=regional-tourism-workshopoct-2018.

39 RFE/RL. 2017. Five Central Asian Nations Sign Cooperation Program at Uzbekistan Meeting. https://www. rferl.org/a/central-asia-cooperation-program-samarkand/28847217.html. 
(iv) Tea Road cooperation between Mongolia and the PRC (and the Russian Federation). ${ }^{40}$

(v) Mongolia's tourism cooperation agreements with 12 countries including CAREC members (Kazakhstan, the Kyrgyz Republic, and the PRC) (footnote 40).

(vi) Kazakhstan's 55 bilateral international documents in the tourism sector, including 13 with fellow CAREC member countries (Azerbaijan, the Kyrgyz Republic, Mongolia, Pakistan, the PRC, Tajikistan, Turkmenistan, and Uzbekistan). ${ }^{41}$

(vii) Azerbaijan's tourism agreements with seven CAREC member states (i.e., Georgia, Kazakhstan, the Kyrgyz Republic, Pakistan, the PRC, Tajikistan, and Turkmenistan). ${ }^{42}$

96. At the same time, high-level talks take place regularly between neighboring CAREC countries to discuss increased cooperation in tourism in factors such as visa arrangements and direct air connections. Also, as recorded in section 5.3., there are a range of tour programs on the market that feature combinations between two and up to eight CAREC countries, mostly under the umbrella of the Silk Road. These cater to specific tourism segments, and demand is still modest.

97. The principal existing regional tourism cooperation initiative within the CAREC region is between Kazakhstan and the Kyrgyz Republic through the Almaty-Bishkek Economic Corridor (ABEC) program. Kazakhstan and the Kyrgyz Republic, through the ABEC subcommittee, signed a protocol in June 2018 on priority areas of tourism and urban development. The protocol agreed to

(i) address the existing and growing skill gap as a binding constraint for the development of a high-quality tourism sector in both countries,

(ii) give importance to coordinated approaches for developing and managing joint tourist destinations for the subsequent international promotion and joint branding to ensure recognizability,

(iii) use ADB technical assistance to draft the master plan on Central TianShan mountainous cluster on both sides of ABEC corridor,

40 Mongolia Presentation. CAREC Regional Workshop_-Promoting Regional Tourism Cooperation under CAREC 2030, Tashkent, Uzbekistan. October 2018. https://www.carecprogram.org/?event=regionaltourism-workshop-oct-2018

${ }^{41}$ Government of Kazakhstan, National Chamber of Commerce, and Kazakh Tourism. Tourism in the Republic of Kazakhstan. Presentation at CAREC Regional Workshop-Promoting Regional Tourism Cooperation under CAREC 2030, Tashkent, Uzbekistan. October 2018. https://www.carecprogram. org/?event=regional-tourism-workshop-oct-2018.

42 Azerbaijan Presentation. CAREC Regional Workshop_Promoting Regional Tourism Cooperation under CAREC 2030, Tashkent, Uzbekistan. October 2018. https://www.carecprogram.org/? event=regionaltourism-workshop-oct-2018.

While high-level talks regularly take place between CAREC countries for increased tourism cooperation, their potential could be significantly increased if access was made easier and visitors could combine their trips to two or more countries. 
In promoting a regional approach to tourism development, CAREC can learn from the experience of other regional programs such as the Greater Mekong Subregion. (iv) use ADB technical assistance for institutional development and capacity building of relevant tourism agencies in the two countries, and

(v) support health tourism development as part of ABEC activities.

98. Best practices in regional tourism cooperation. The Greater Mekong Subregion (GMS) Program ${ }^{43}$ has over a decade's experience in developing and promoting the Mekong subregion as a single destination with diverse, quality, and high-yielding subregional products that distribute tourism benefits widely. ${ }^{44}$ As such, the GMS offers guiding principles and examples of best practice in multicountry collaboration in the facilitation, development, operation, and marketing of their members' tourism sectors.

99. The GMS' tourism cooperation strategic framework has five main strategic directions, which are further disaggregated into 21 subprograms (Appendix 2). The five strategic directions include (i) human resource development, (ii) improve tourism infrastructure, (iii) enhance visitor experiences and services, (iv) creative marketing and promotion, and (v) facilitate regional travel. In addition, the Mekong Tourism Coordinating Office identifies five key areas which inform and dictate the region's approaches to its tourism development and integration strategies. These include

(i) developing tourism strategy driven by public and private sectors;

(ii) delivering on visitors' expectations in terms of products, experiences, service, and infrastructure;

(iii) creating a culture of collaboration, contribution, and engagement to create value for all stakeholders;

(iv) leveraging digital means to communicate with industry and show a leadership position in industry; and

(v) building relationships with development partners, and national as well as global industry associations. ${ }^{45}$

100. Each of these lessons and strategic directions is fully relevant to the CAREC region's future approach to the development of its members' tourism sectors and the integration of their strategies aimed at realizing the opportunities provided by their tourism resource strengths.

43 The Greater Mekong Subregion comprises Cambodia, the Lao People's Democratic Republic, Myanmar, Yunnan Province and the Guangxi Zhuang Autonomous Region in the People's Republic of China, Thailand, and Viet Nam.

44 Mekong Tourism Coordinating Office. 2017. The Greater Mekong Subregion Tourism Sector Strategy 2016-2025. Bangkok.

45 Mekong Tourism. 2018. Mekong Tourism Regional Tourism Strategy and Initiatives. Presentation at CAREC Regional Workshop, Tashkent, Uzbekistan. October 2018. 


\subsection{Potential Regional Tourism Clusters and Partnerships}

101. In considering the mechanics of how greater cooperation and integration in tourism can be achieved in a tourist-friendly and logistically practical way, and noting the likely realities of visitor length-of-stay in the region per trip, there is an opportunity to develop subgroupings (intercountry) within the wider CAREC region. The following regional clusters and partnerships can be identified, based on geographical proximity to each other and/or existing regional or thematic tour programs:

\subsubsection{Subregional Partnerships based on Geographical Proximity and Shared Geographical Features}

(i) Caucasus: Azerbaijan and Georgia;

(ii) Caspian Sea: Azerbaijan, western Kazakhstan, and Turkmenistan;

(iii) Almaty-Bishkek Economic Corridor: southeastern Kazakhstan and the Kyrgyz Republic;

(iv) Central Core States: southeastern Kazakhstan, the Kyrgyz Republic, Tajikistan, and Uzbekistan;

(v) Eastern Subregion: Mongolia and the PRC autonomous regions;

(vi) Himalayas: Afghanistan and Pakistan;

(vii) Altai region: Kazakhstan, Mongolia, and Xinjiang Uygur Autonomous Region;

(viii) Pamir mountain range: Afghanistan, the Kyrgyz Republic, and Tajikistan;

(ix) Rivers and seas: the Amu Darya and Siri Darya (better known by their classical names, the Oxus and the Jaxartes), the Indus, the Caspian, and the Aral Seas; and

(x) Desert tourism: The Gobi (northern PRC and Mongolia), Karakum (Turkmenistan), Kyzylkum (Kazakhstan and Uzbekistan), Takla Makan (Xinjiang Uygur Autonomous Region, one of the largest deserts in the world), and the subtropical Thar (Pakistan).

\subsubsection{Subregional Thematic-Based Partnerships}

(i) Mountain trekking and climbing: Afghanistan and Pakistan; the Kyrgyz Republic and Tajikistan; Tajikistan and Uzbekistan; Kazakhstan and the Kyrgyz Republic;

(ii) Cultural heritage: all countries have shared aspects of heritage with their neighbors: UNESCO sites offer an immediate opportunity for cross-border visits;
Subgroupings within the CAREC region could be developed to take forward regional tourism initiatives in a pragmatic manner. 
(iii) Mountain and cultural and historic features: Afghanistan, Pakistan, Tajikistan, and the Kyrgyz Republic (Wakhan Pamir), plus Uzbekistan (Lapis Mines), ecotourism and wildlife, nomadic cultures;

(iv) Religions: Buddhism, Islam and Islamic architecture, Christianity in the east and west;

(v) Historical figures: Alexander the Great, Emperor Wu of Han, Genghis Khan, Temur the Great, Babur, explorers through the region, such as Zhang Qian, Ibn Battuta, and many more;

(vi) Trade goods: silk, salt, tea, crafts;

(vii) The Great Game then and now: Britain, Imperial Russia, post-Soviet relics and today's evolving picture; and

(viii) The Silk Roads.

102. Clearly, the past, current, and planned development of the tourism potential of the historic Silk Road routes from the PRC across Asia and into the Middle East, Europe, and Africa, represents a major opportunity for the nations along its various paths to work with each other. There are a range of possible collaborations involving several CAREC countries, namely the PRC's Xinjiang Uygur Autonomous, Afghanistan, Kazakhstan, the Kyrgyz Republic, Pakistan, Tajikistan, Turkmenistan, and Uzbekistan. The situation regarding the PRC's Belt and Road Initiative is evolving all the time and all CAREC countries are engaged in the evolving Belt and Road Initiative to differing degrees.

103. Silk Roads routes are many. One runs through southeastern Kazakhstan (Almaty), the Kyrgyz Republic (Bishkek), southeastern Uzbekistan (Samarkand), and Tajikistan (Dushanbe). The Northern route connects Xinjiang Uygur Autonomous Region with Southeastern Kazakhstan, then splitting to (i) Southern Uzbekistan, Afghanistan and on to Turkmenistan, and (ii) Eastern Uzbekistan across the Karakum Desert and joining up with the other route in Turkmenistan. The southern route goes across the Karakorum Mountains into northern Pakistan, Afghanistan, rejoining the northern route in Turkmenistan, and on to Iran. A southwestern route runs through Myanmar and Bangladesh.

104. Originally referred to as "One Belt One Road" (the belt crosses the land and the road crosses the sea), in recent times, "Belt and Road Initiative" is the preferred term in English, which more accurately reflects the fact that multiple routes are being developed. The overall framework covers various infrastructure development and connectivity-enhancing projects across Africa, Asia, and Europe. When originally launched as One Belt One Road in 2013, the initiative mainly focused on countries of Central Asia and the Association of Southeast Asian Nations. This further progressed into two intercontinental trajectoriesmaritime and overland-connected by a network of port, rail, road, and pipeline infrastructure through six corridors. Three of these pass through the CAREC region: The New Eurasia Landbridge, the PRC-Mongolia-Russia Economic Corridor, and the PRC-Pakistan Economic Corridor. 
105. The UNWTO noted that the proposed infrastructure developments will over time have a significant impact in terms the geography of tourism, the scale of the industry, and its tourism product offering. Improved transport links and new gateways will make previously unknown destinations more accessible to international tourists. ${ }^{46}$ Cultural exchange is one of five cooperation priorities of the Belt and Road Initiative. According to the secretary-general of the Beijingbased World Tourism Cities Federation, the PRC is expected to send 150 million visitors to Belt and Road cities and countries over the next 5 years. The PRC expects to attract 85 million visits from tourists of these areas. ${ }^{47}$ In addition, a Belt and Road Strategy for sports tourism has been published. ${ }^{48}$

\subsection{Range of Regional Tourism Cooperation and Integration Opportunities}

106. Opportunities exist to address the shortcomings identified in Chapter 4 through collaboration among CAREC countries to ensure consistency and harmonization in matters such as (i) visas and other entry requirements (e.g., Silk Road visa proposal), (ii) aviation rights, (iii) tourist facility standards and certification, (iv) tourism staffeducation and training curricula and qualifications, (v) foreign investment conditions, and (vi) regional and subregional destination brand and image development.

107. These opportunities are only specifically stated to be tackled on a regional basis in the official document of Uzbekistan, ${ }^{49}$ though other countries (e.g., Tajikistan) mention the development of international cooperation as a guiding principle. Media reports indicate that regional tourism cooperation is the subject of many high-level bilateral and regional consultations between CAREC country officials that have taken place over the past year or are ongoing at the time of drafting.

\subsubsection{Visa and Entry Facilitation}

108. While the ultimate goal would be the elimination of visa requirements for travel to and between CAREC countries, the ability to obtain visas-on-arrival or online e-visas would be welcomed by the international traveling public and make the region more tourist-friendly. CAREC countries could work with each other to establish entry requirements that are (i) common across all CAREC

46 UNWTO. 2018. The 21st Century Maritime Silk Road: Tourism Opportunities and Impacts. Madrid: World Tourism Organization

47 Yang. 2017. New Pact to Boost Tourism under Belt and Road Initiative. China Daily (electronic).http:// www.chinadaily.com.cn (accessed 21 October 2017).

${ }^{48}$ General Administration of Sport of China. 2017. Notice of the National Tourism Administration of the State Sports General Administration on Printing and Distributing the "Action Plan for the Development of Sports Tourism." Beijing.

${ }^{49}$ Government of Uzbekistan. 2016. The Concept of Uzbekistan's Tourist Industry Development for the Medium Term 2017-2021. Tashkent.
CAREC countries could work with each other to establish common and tourist-friendly visa and entry requirements. 
countries, and (ii) do not necessitate making in-person or e-mail application ahead of travel. At immigration counters in airports, separate lanes can be introduced for fellow CAREC country citizens, and international tourists. Again, a common format with signage using the same wording would be helpful for arriving travelers.

\subsubsection{Aviation Rights}

109. The conclusions and findings of the CAREC Aviation Scoping Study are fully endorsed:

(i) A more open CAREC aviation market will reduce transport costs and travel times, leading to direct benefits to governments, the private sector, and consumers.

(ii) A phased approach to aviation market liberalization will attract investment in infrastructure and opportunities for aviation service suppliers such as airlines, ground handlers, catering, maintenance, and cargo operations, while at the same time not disrupt the existing market.

(iii) The phased transition toward a more open aviation sector model should initially focus on such investments opportunities within the CAREC region and regulatory harmonization.

(iv) CAREC should also facilitate investment in critical missing infrastructure links in the aviation sector, including airport facilities and equipment at both international hubs, as well as secondary cities. Such investments will benefit from the early engagement of potential financing partners, as well as the encouragement of private sector involvement through public-private partnership structures.

\subsubsection{Tourist Facility Standards and Certification}

110. CAREC countries recognize the need to upgrade their tourism facilities and operations but, rather than tackling this task individually, they would benefit from working with other CAREC countries to develop common standards and a shared certification scheme, recognized internationally. This will provide increased assurance in the marketplace and contribute to the establishment of the perception of the CAREC region as a strong destination for both travelers from other CAREC countries and international tourists. The ASEAN Community-Based Tourism Standard covering the full range of tourism operations and service is a sound model for the CAREC countries to examine and emulate. ${ }^{50}$

\footnotetext{
50 ASEAN. 2016. ASEAN Community-Based Tourism Standard. Jakarta.
} 


\subsubsection{Tourism Education and Training}

111. As tourism assumes an increasing role in the economy of CAREC countries, of growing importance will be the need to plan and manage the sector in full cognizance of both international market conditions and the levels and types of tourism that the individual countries' natural and cultural resources can sustain without deleterious impacts. An adequate supply of qualified tourism planning officials and managers will be needed.

112. These officials and managers can initially be educated through cooperation with overseas institutions, but local universities can also play an important role. The commencement of tourism courses at the Silk Road International Tourism University in Samarkand (Uzbekistan) for the 20182019 academic year is a particularly encouraging development. About 125 undergraduates are studying tourism through design, marketing, services technology, logistics, professional education, hotel business, catering business, and event management. ${ }^{51}$ The Government of Kazakhstan is also planning to open a tourism and hospitality university in Astana (footnote 41).

113. Tourism staff in operational contact with tourists have three categories of skills: technical, linguistic, and social. Technical and linguistic skills can be taught through common curricula based on international systems, with qualifications and certification for those that achieve the standards required, serving both to ensure a high level of service provision is achieved, and to reassure tourists that service in CAREC countries is in line with international norms. Social skills can be partly taught, but sufficient freedom should be allowed for trainees to express their own character, thereby ensuring that service is not totally homogeneous across all countries. Training programs can be established in each country using the same curricula and qualification requirements, or organized subregionally with students from two or more countries being taught together.

\subsubsection{Foreign Investment Conditions}

114. In the development of an economic sector such as tourism, there is a necessary balance between CAREC countries' national and regional interests. While each country will have its own goals and conditions for foreign investment in the tourism sector and related infrastructure, there will be wider benefit for the whole region if there is a common framework that prospective investors can relate to in considering their chosen investments. This is not to say all CAREC countries should have the same regulations and terms for foreign investment, but a standard framework will serve to encourage investors to give serious consideration to options in the CAREC region as opposed to other parts of the world.
An adequate supply of qualified tourism planning officials and managers is key to keep up with the increasing role of tourism in the economy of CAREC countries.

51 Uzbekistan National News Agency. Silk Road International Tourism University is Ready for Tests. 24 July 2018. Tashkent 
CAREC countries have the opportunity to align their tourism promotion strategies and undertake collective marketing actions under the Silk Road brand.

\subsubsection{Brand and Image Development}

115. The CAREC countries' most fundamental need in the international market is building a perception that the countries are, both individually and in combination, destinations that (i) offer a wide range of outstanding tourism experiences with high-quality facilities and standards, (ii) are easy to reach and travel around in and between, and (iii) provide a safe and secure environment.

116. The need to develop a coherent and persuasive positive tourism image for the CAREC region as a whole would be an ultimate, long-term goal but, in the short to medium term, the focus can most profitably be on creating strong images and brands for subregional partnerships between countries with shared resources and potential to attract visitors on multicountry tours.

117. It should also be borne in mind that the CAREC region's geographic spread is vast and the primary international markets for countries varies widely, with European tourists more likely to visit the Caucasus countries and Asian tourists choosing destinations in the eastern part of the region. The number of tourists with the time and resources to visit the whole region is likely to be very small, but this does not mean that collective image-building should be ignored, and the value of the existing Silk Road profile is noted (footnote 23).

118. Where common resources exist for tourism development-some of which are already offered in multicountry tour packages-as well as shared social, economic, and political factors, and air (and other) transport connections, typically with neighboring countries, the possibility exists of undertaking joint marketing and promotion to create a set of subregional brands. This approach is the most straightforward and is probably the quickest for achieving a positive image geared toward the preferences of each subregion's target markets, and for delivering measurable results.

119. Clearly, primary market research into main target markets will be required to verify current perceptions and test possible future marketing concepts (for both CAREC region overall as a possible tourism brand, and for subregional brands between countries). Without such research, collective marketing would be high risk and likely returns could not be accurately estimated.

120. An overall CAREC tourism marketing office can help ensure a degree of consistency and compatibility, initially between campaigns of the different subregions, and with the ultimate goal of creating a CAREC-wide image in the marketplace as a set of countries with an outstanding range of natural and cultural heritage resources not found in any other part of the world, and with service standards to match.

121. CAREC countries have the opportunity to align and coordinate their regional (and national) tourism marketing strategies with the Silk Road brand. The growing positive image of the Silk Road, as borne out by TripAdvisor research (footnote 23), can help the CAREC countries boost their status as 
key destinations on the various branches of the Silk Road. However, as noted in the TripAdvisor study, strong efforts will be needed to rectify the prevailing impression of the study's respondents that CAREC countries are not currently among the principal destinations to be visited on the Silk Road.

\subsection{Tourism Product Development: The Importance of Market Knowledge and Research}

122. Implementation of the types of regional cooperation opportunities identified in the preceding chapters of the report will not have a significant impact on tourist flows unless the CAREC countries have the range of tourism products that appeal to the key international and regional tourist market segments: product-market matching principle (i.e., the tourism products offered match the market demand).

123. The CAREC countries' policy and strategic planning documents focus on the need

(i) to expand and upgrade the range of their tourism products to broaden the appeal of the country to other market segments;

(ii) to create clusters of tourism products related to specific themes-with the goal to create a package of attractions and activities of sufficient scale and quality to influence the decision to visit the destination positively;

(iii) to spread the socio-economic benefits derived from tourism development by focusing on the countries' regions; and

(iv) to create year-round tourist attractions so that tourism demand is not subject to wide seasonal imbalances.

124. Details of the tourism product development intentions of the nine CAREC countries - for which official policy, strategy, and planning documents were submitted to the CAREC Secretariat-are summarized in Table 8. These indicate highly ambitious intentions. However, significant public sector support for infrastructure provision, investment incentives, and marketing and promotion support will be needed to turn these goals into a realized, extensive program of profitable product developments.

125. To be able to select the most appropriate product developments to be prioritized, insight into the market potential of each option is essential. That necessitates in-depth market knowledge so that not only those products with the greatest potential can be selected, but also the most effective means of communicating with the market segments to which such products appeal can be identified. 


\section{Table 8: Tourism Priorities, Goals, Strategies, and Targets of CAREC Countries}

\begin{tabular}{|c|c|}
\hline Country & Product Development Plans \\
\hline Azerbaijan & $\begin{array}{l}\text { - Baku City and throughout the country. } \\
\text { - Health, winter, cultural, business, ecotourism, mountain, sport, } \\
\text { hunting, beach, and village. }\end{array}$ \\
\hline Georgia & $\begin{array}{l}\text { - Ecotourism, nature tourism, skiing, hiking, mountain biking, water } \\
\text { sports (on Black Sea coastline), and other forms of adventure and } \\
\text { outdoor leisure and recreational pursuits. } \\
\text { - Business tourism-meetings, incentives, conferences and } \\
\text { exhibitions. }\end{array}$ \\
\hline Kazakhstan & $\begin{array}{l}\text { Creation of tourism product clusters around the country, with } 6 \text { foci: } \\
\text { - Astana-heart of Eurasia; } \\
\text { - Almaty-free cultural zone of Kazakhstan; } \\
\text { - Pearl of Altai centered on Ust-Kamenogorsk in north and east part } \\
\text { of eastern Kazakhstan; } \\
\text { - Revival of the Great Silk Road, including the central and eastern } \\
\text { parts of the Kyzylorda region, the southeastern and northwestern } \\
\text { parts of the South Kazakhstan region and the southwestern part of } \\
\text { the Zhambyl region; } \\
\text { - Caspian Gates, centered on Aktau City, including all of the } \\
\text { Mangistau region and part of the West Kazakhstan and Atyrau } \\
\text { regions; } \\
\text { - Unity of nature and nomadic culture, centered on the Schuchinsk- } \\
\text { Burabay resort zone, including Akmola and Karaganda regions, and } \\
\text { western parts of North Kazakhstan and Pavlodar regions. }\end{array}$ \\
\hline Kyrgyz Republic & $\begin{array}{l}\text { - Clusters for skiing, year-round resort and recreation, cultural } \\
\text { and educational development along the Silk Road, business } \\
\text { tourism, international events-ethnic games, arts, competitions, } \\
\text { exhibitions, and sports. }\end{array}$ \\
\hline Mongolia & $\begin{array}{l}\text { - New airport with a tourism-free zone. } \\
\text { - Temporary stopping points and service areas nearby main tourism } \\
\text { routes. } \\
\text { - Formulation of tourism development programs, establishment } \\
\text { of specialized tourism complexes, and development of branded } \\
\text { products and services in the provinces and advertise these abroad } \\
\text { and at home. }\end{array}$ \\
\hline Pakistan & $\begin{array}{l}\text { - Tourism product development planned at provincial level. } \\
\text { - Cultural sites, sports and cultural shows; adventure tourism; } \\
\text { ecotourism and nature-based tourism; religious tourism; overseas } \\
\text { Pakistanis. }\end{array}$ \\
\hline $\begin{array}{l}\text { PRC-Inner Mongolia } \\
\text { Autonomous Region }\end{array}$ & $\begin{array}{l}\text { - Whole-area and four-season tourism. } \\
\text { - Leisure, snow, outdoor, culture, red revolution, border, and cross- } \\
\text { border, action-learning, industrial tourism. }\end{array}$ \\
\hline $\begin{array}{l}\text { PRC-Xinjiang Uygur } \\
\text { Autonomous Region }\end{array}$ & $\begin{array}{l}\text { - Urumqi as tourism hub for the Silk Road Economic Belt. } \\
\text { - Ethnic culture in South Xinjiang, world heritage tourism industry } \\
\text { belt of Tian Shan Mountain corridor. }\end{array}$ \\
\hline Tajikistan & $\begin{array}{l}\text { - New tourism products and routes, focused on the } 2018 \text { Year of } \\
\text { Tourism and Folk Crafts development. }\end{array}$ \\
\hline
\end{tabular}


Table 8 continued

Country
Uzbekistan

Source: Summaries of the official policies and strategic plans, Appendix 1.

126. It is noted that many of the official tourism development strategic plans focus on improving the state's ability to collect and analyze statistics and undertake market research. Collecting and analyzing information about current visitors, and analyses gleaned from studies undertaken by agencies like the UNWTO, will assist CAREC countries in identifying the most promising market segments, the types of experiences in which they wish to engage, and their attitudes, motivations, and behavioral patterns. Joint investment in, and sharing the results of, market research surveys between subgroups or all CAREC countries is a clear opportunity for regional cooperation. Such information will enable both appropriate types of tourism products to be developed, encouraged, and supported; and marketing and promotional campaigns devised that communicate to the most promising markets and segments.

127. The selection of product areas to be prioritized needs to be in line with those markets and segments with the greatest potential. To kick-start the process, and before detailed findings from increased market statistical and research information becomes regularly available, key characteristics can be identified from other countries' research programs which match the planned expanded and improved product and service provision of CAREC countries. These developments will result in increased opportunities in both individual countries and across borders for combined natural and cultural heritage circuits, clearly targeted at the central sections of the tourism demand model in the figure.

128. For instance, the primary segments to which such tours may appeal are identified in research conducted by the Irish tourism authorities for the European and North American markets as the "culturally curious." The profile of this segment can be accessed through the website of Failte Ireland (the Irish Tourist Board). In brief, the culturally curious ${ }^{52}$ are characterized as:

(i) independent "active sightseers" looking to visit new places, and expand their experience by exploring landscapes, history, and culture (including local food), far away from their usual routine and culture;

(ii) the age group for this demographic is 40 plus, often traveling as a couple or as individuals;

\section{Joint investment in, and sharing the results of, market research surveys among CAREC countries is a clear opportunity for regional cooperation.}


CAREC countries are cognizant of the importance of establishing and maintaining regular dialogue among government officials and private sector representatives to advance tourism cooperation. (iii) interested in all that a place has to offer, and attracted to authentic travel; and

(iv) wanting to go at a comfortable and relaxed pace, including by walking.

\subsection{CAREC Regional Tourism Workshop: Survey Results}

129. A regional consultation workshop was held in October 2018 in Tashkent, Uzbekistan. Workshop participants noted the importance of further continuing and advancing tourism cooperation under CAREC through the establishment of an expert group composed of public officials in charge of tourism development and private sector representatives.

130. A questionnaire was distributed to the workshop participants to help identify potential areas and activities that could be supported through technical assistance by ADB and other CAREC development partners going forward (Appendix 4). The suggestions most advocated in the survey of workshop participants included (i) preparing a pipeline of investment projects (both hard and soft infrastructure interventions); (ii) developing standardized skills and training levels to ensure consistent, predictable, and high-quality tourism service provision across the CAREC region; (iii) improving data collection and standardizing tourism statistics, in collaboration with the UNWTO; (iv) conducting market research, with particular emphasis on neighboring regions (the PRC, the Russian Federation, India, and Europe) and intraregional tourism; (v) preparing a CAREC tourism strategy (along the GMS model); (vi) developing a virtual CAREC tourism portal for consolidating and disseminating information; (vii) assessing the status and scope of visa harmonization in the CAREC region; (viii) identifying partnerships and sources of financing, and providing support to existing intercountry routes in coordination with other development partners and regional initiatives; and (ix) developing tourism infrastructure.

131. Other suggested areas included promoting sustainable and communitybased tourism, particularly in remote and rural areas; supporting pilot projects along ABEC; building capacity of tourism-related agencies, including at provincial level; and organizing conferences and investment forums to enhance public-private coordination and collaboration. 


\section{CAREC Regional Tourism Cooperation: Recommendations}

132. Based on the analysis conducted in the preceding sections of the scoping study, a series of proposed policy recommendations are summarized in Table 9. These are divided into the six broad categories related to regional tourism development: (i) accessibility and infrastructure, (ii) tourism products and experiences, (iii) tourism skills and services, (iv) marketing and promotion, (v) financing and other support, and (vi) organization and institutions.

\section{Table 9: Summary of Recommendations}

\begin{tabular}{|c|c|}
\hline Category & Recommendation \\
\hline $\begin{array}{l}\text { Accessibility and } \\
\text { infrastructure }\end{array}$ & $\begin{array}{l}\text { - Facilitate common procedures to make visa processes more uniform } \\
\text { and tourist-friendly. } \\
\text { - Implement the recommendations of the CAREC Aviation Scoping } \\
\text { Study to increase and improve air transport connectivity into, and } \\
\text { between, CAREC countries. } \\
\text { - Upgrade land transport facilities on cross-border routes used by tour } \\
\text { operators. }\end{array}$ \\
\hline $\begin{array}{l}\text { Tourism products } \\
\text { and experiences }\end{array}$ & $\begin{array}{l}\text { - Further exploit the impetus created by ongoing international support for } \\
\text { the development of Silk Road routes for tourism purposes. } \\
\text { - Develop appropriate tourism experiences (along with upgraded and } \\
\text { expanded facility and service standards) for all markets on a product- } \\
\text { market matching principle. } \\
\text { - Establish and implement across all CAREC countries certification } \\
\text { schemes for the different types of tourism facility. }\end{array}$ \\
\hline $\begin{array}{l}\text { Tourism skills and } \\
\text { services }\end{array}$ & $\begin{array}{l}\text { - Develop tourism education and training courses, on both a national and } \\
\text { subregional basis, to common curricula and qualifications. } \\
\text { - Work with the UNWTO Silk Road University (Samarkand) and other } \\
\text { institutions to develop specialist training and encourage other inter- } \\
\text { university tourism partnerships. }\end{array}$ \\
\hline $\begin{array}{l}\text { Marketing and } \\
\text { promotion }\end{array}$ & $\begin{array}{l}\text { - Establish a CAREC virtual tourism support database to strengthen } \\
\text { the collection of tourism statistics and to share statistics and market } \\
\text { knowledge. } \\
\text { - Create destination image and branding on a subregional basis under the } \\
\text { overall Silk Road region marketing umbrella. } \\
\text { - Strengthen collaboration with the UNWTO Silk Road Programme and } \\
\text { UNESCO (including market research on UNESCO-designated sites } \\
\text { and natural and cultural heritage for creating destination image and } \\
\text { branding). }\end{array}$ \\
\hline
\end{tabular}


Table 9 continued

\begin{tabular}{ll} 
Category & \multicolumn{1}{c}{ Recommendation } \\
$\begin{array}{l}\text { Financing and } \\
\text { other support }\end{array}$ & $\begin{array}{l}\text { - Develop a standard regional investment framework for foreign investors. } \\
\text { - Identify funding support mechanisms to accelerate access } \\
\text { improvements, product development, and marketing of CAREC } \\
\text { and its subregions, i.e., sovereign lending, technical assistance, and } \\
\text { nonsovereign lending. }\end{array}$ \\
Organization and & - Establish a CAREC tourism expert group to advance tourism work \\
institutions & and cooperation and improve public-private coordination and \\
& collaboration. \\
& Develop subregional partnerships of countries willing to work on joint \\
& activities (e.g., in product development, cross-border tourism, and \\
& marketing). \\
& Develop a more detailed medium-term CAREC Tourism Strategy, \\
& setting out a vision and road map for 2030.
\end{tabular}

CAREC = Central Asia Regional Economic Cooperation, UNESCO = United Nations Educational, Scientific and Cultural Organization, UNWTO = United Nations World Tourism Organization.

Source: CAREC Secretariat.

133. In taking forward these recommendations, technical assistance (TA) could be provided from ADB and other CAREC development partners. The specifics of the TA should be determined through consultation with the CAREC tourism expert group. Potential activities suggested by member countries at the regional tourism workshop provide a good starting point for taking this work forward (section 6.6. and Appendix 4).

134. Regional initiatives could be implemented in partnership with a range of international and bilateral donor organizations such as the UNWTO, UNESCO, the Standing Committee for Economic and Commercial Cooperation of the Organization of the Islamic Cooperation, the Silk Road Development Fund, the EU and other lending institutions and donors. Examples of such collaboration could include (i) building synergies and supporting the recently launched UNESCO and EU project on Silk Roads Heritage Corridors in Afghanistan, Central Asia, and Iran; (ii) promoting cultural and natural heritage-based tourism in CAREC countries through capacity building and promotional activities, including drawing on UNESCO and UNWTO experience working with journalists and the travel trade; (iii) undertaking research on UNESCOdesignated sites and natural and cultural heritage for creating destination image and branding, including on a sub-regional basis; and (iv) undertaking market research in partnership with organizations such as TripAdvisor (a UNWTO Affiliate Member). 


\section{Summaries of Tourism Priorities, Strategies, and Targets for CAREC Members}

\begin{tabular}{|c|c|c|c|}
\hline Country & Priorities and/or Goals & Strategies & Targets \\
\hline Azerbaijan & $\begin{array}{l}\text { Strategic Road Map on Tourism } \\
\text { Industry Development } \\
\text { - Simplify and accelerate visa } \\
\text { clearance and border crossing } \\
\text { procedures. } \\
\text { - Facilitate air connection with } \\
\text { main tourist source markets. } \\
\text { - Develop tourism infrastructure. } \\
\text { - Organize relevant marketing and } \\
\text { promotion campaigns. } \\
\text { - Develop a diversified and } \\
\text { sustainable set of tourism } \\
\text { products. } \\
\text { - Update information on tourism } \\
\text { areas and services. } \\
\text { - Invest in tourism sector } \\
\text { educational programs. }\end{array}$ & $\begin{array}{l}\text { Strategic targets: } \\
\text { - Major increase in foreign tourism } \\
\text { to Baku City. } \\
\text { - Creation of necessary } \\
\text { environment for tourism } \\
\text { development throughout the } \\
\text { country. } \\
\text { - Develop regional tourism types. } \\
\text { - Create a range of tourism } \\
\text { products: health, winter, cultural, } \\
\text { business, ecotourism, mountain, } \\
\text { sport, hunting, beach, and village. } \\
\text { - Create national tourism quality } \\
\text { system to increase tourist } \\
\text { satisfaction levels. } \\
\text { - Focus marketing on five main } \\
\text { source markets: domestic, } \\
\text { neighboring countries, Middle } \\
\text { East, CIS members, mass markets, } \\
\text { such as US, PRC, and EU. }\end{array}$ & $\begin{array}{l}\text { By 2020: } \\
\text { - Increase country's real GDP to } \\
\text { AZN465 million ( } \$ 274.1 \text { million) } \\
\text { - Increase employment by } 35,000 \text {; } \\
25,000 \text { in tourism. } \\
\text { - Increase foreign citizens' } \\
\text { overnight stays in hotels between } \\
2015 \text { and } 2020 \text { from } 0.8 \text { million } \\
\text { to a minimum of } 3.65 \text { million } \\
\text { nights. } \\
\text { - Increase length of stay from } 2 \text { to } \\
3 \text { days. } \\
\text { - Attract over } 180,000 \text { tourists at } \\
\text { places along the Great Silk Road } \\
\text { and other cultural tourism routes. } \\
\text { - Invest AZN350 million } \\
\text { ( } \$ 206.3 \text { million) a year from } \\
\text { public, private, and international } \\
\text { sources. }\end{array}$ \\
\hline Geo & $\begin{array}{l}\text { Georgia National Tourism Strategy } \\
\text { 2025: } \\
\text { - Create unique, high-quality } \\
\text { visitor experiences in line with } \\
\text { demand in the highest spending } \\
\text { outbound markets, based on the } \\
\text { country's cultural and natural } \\
\text { assets. } \\
\text { - Improve air access from those } \\
\text { high spending markets, and } \\
\text { internal transport networks to } \\
\text { facilitate the free flow of visitors } \\
\text { to and within the country. } \\
\text { - Improve data collection and } \\
\text { market research capabilities, to } \\
\text { better understand the demands } \\
\text { and preferences of higher } \\
\text { spending markets. } \\
\text { - Use that research and additional } \\
\text { marketing resources to } \\
\text { more effectively target and } \\
\text { communicate with these markets } \\
\text { and raise awareness of Georgia as } \\
\text { a world-class tourism destination. }\end{array}$ & $\begin{array}{l}\text { Policy Tools to Achieve Targets: } \\
\text { Inbound Tourism Revenues: } \\
\text { - Promotional activities in } \\
\text { international markets. } \\
\text { - Concentration on tapping into } \\
\text { high-income markets. } \\
\text { - High-quality service. } \\
\text { Tourism Contribution to GDP: } \\
\text { - Attraction of investments in the } \\
\text { sphere of tourism. } \\
\text { - Development of new tourism } \\
\text { products: ecotourism or nature } \\
\text { tourism, skiing, hiking, mountain } \\
\text { biking, water sports (on Black } \\
\text { Sea coastline), and other forms } \\
\text { of adventure and outdoor leisure } \\
\text { and recreational pursuits. } \\
\text { - Business tourism-MICE } \\
\text { Annual Increase in Tourism Jobs: } \\
\text { - Trainings, lectures, and } \\
\text { workshops for the persons } \\
\text { employed in tourism sector. } \\
\text { - Marketing incentive programs }\end{array}$ & $\begin{array}{l}\text { 2015-2025 Targets: } \\
\text { - Increase tourism receipts from } \\
\text { the current level of } \$ 1.9 \text { billion to } \\
\text { - In.6 billion. } \\
\text { - expenditure from } \$ 328 \text { to } \$ 600 \text {. } \\
\text { - Increase the industry's direct } \\
\text { contribution to GDP to } 7.9 \% \text {. } \\
\text { - Increase the number of } \\
\text { Georgians employed in tourism } \\
\text { by } 90 \% \text { to over } 300,000 \text {. } \\
\text { - Increase foreign direct } \\
\text { investment (FDI) from tourism } \\
\text { industry by } 63 \% \text {, to } \$ 1.18 \text { billion. } \\
\text { - Double the number of visitors } \\
\text { from higher spending markets } \\
\text { of Western Europe, Asia, and } \\
\text { North America. } \\
\text { - Extend the average length of stay } \\
\text { from } 5 \text { to } 7 \text { days. }\end{array}$ \\
\hline
\end{tabular}


Appendix 1 Table continued

\begin{tabular}{ll} 
Country & \multicolumn{1}{c}{ Priorities and/or Goals } \\
Georgia & Improve visitor services, \\
& from transportation to \\
accommodations and \\
interpretation, to realize the \\
potential from the expanded and \\
targeted marketing efforts, and to \\
ensure positive, word-of-mouth \\
advertising and repeat visits.
\end{tabular}

\section{Kazakhstan Development of the Tourist Industry until 2023:}

- Development of domestic tourism.

- Development of regional cultural and tourist clusters.

- Increasing the contribution of the tourism industry to the economy of the state, stimulating investment.

- Creation of jobs in the tourism industry and related industries.

Strategies

Targets

\section{Average Spending per Visitor:}

- Concentration on high-spender segments.

- Improvement and diversification of services.

\section{Average Length of Stay:}

- Marketing campaigns concentrating on international visitors with longer period of stay.

\section{Monthly Average Number of} Domestic Trips:

- Promotional activities on domestic market.

- Development of tourism infrastructure.

- Marketing incentive programs based on innovative tourist products and services (promote tours: education, youth programs, family visits, festivals, and events, and others).

- Improvement of service quality (direct access and availability to the services).

\section{Foreign Direct Investments in}

\section{Tourism Sector:}

- Development of tourism infrastructure.

- Increase of awareness about Georgia.

Structure of International Arrivals:

- Marketing campaigns.

- Concentration on tapping into new markets.

- Promotional activities in new markets.

- Participation in international travel fairs.

- Creation of tourism product clusters around the country, with six foci:

Astana-heart of Eurasia; Almaty-free cultural zone of Kazakhstan; Pearl of Altai centered on Ust-Kamenogorsk in the north and east part of eastern Kazakhstan; Revival of the Great Silk Road including the central and eastern parts of the Kyzylorda region, the southeastern and northwestern parts of the South Kazakhstan region and the southwestern part

\section{Target Increases:}

- Expenditure on accommodations and meals to KZT875 billion ( $\$ 2.4$ billion).

- Output of passenger air services to KZT380.0 billion ( $\$ 1.03$ billion).

- Bed nights in commercial accommodations to 15 million.

- Number of domestic tourists to 12 million. 
Appendix 1 Table continued

\begin{tabular}{|c|c|c|}
\hline Country & Priorities and/or Goals & Strategies \\
\hline Kazakhstan & $\begin{array}{l}\text { - Development of } \\
\text { entrepreneurship, including small } \\
\text { and medium-sized enterprises in } \\
\text { related sectors of the economy, } \\
\text { and human potential, in general, } \\
\text { across the country and regions, } \\
\text { including rural areas. } \\
\text { - Improving the quality of the } \\
\text { tourist product and ensuring its } \\
\text { competitiveness. } \\
\text { - Planning of tourism development, } \\
\text { including in the field of specially } \\
\text { protected natural territories. } \\
\text { - Ensuring the further development } \\
\text { of the tourism infrastructure. } \\
\text { - Promotion of tourist destinations } \\
\text { in the domestic and international } \\
\text { markets. } \\
\text { - Formation of a single national } \\
\text { tourism brand. }\end{array}$ & $\begin{array}{l}\text { of the Zhambyl region; Caspian } \\
\text { Gates, centered on Aktau City, } \\
\text { including all of the Mangistau } \\
\text { region and part of the West } \\
\text { Kazakhstan and Atyrau regions; } \\
\text { Unity of Nature and Nomadic } \\
\text { Culture, centered on the } \\
\text { Schuchinsk-Burabay resort } \\
\text { zone, including the Akmola and } \\
\text { Karaganda regions, and western } \\
\text { parts of North Kazakhstan and } \\
\text { Pavlodar regions. } \\
\text { - Matching tourism product } \\
\text { development to market } \\
\text { segments. } \\
\text { - Training for the tourism industry } \\
\text { to improve service. } \\
\text { - Implementation of regulations } \\
\text { and standards for tourism } \\
\text { services. } \\
\text { - Improving and expanding } \\
\text { transport infrastructure. } \\
\text { - High-quality information to } \\
\text { tourists and investors. } \\
\text { - Institutional reforms. } \\
\text { - Image strategy: revised } \\
\text { approaches to the promotion of } \\
\text { Kazakhstan's tourism products } \\
\text { abroad. }\end{array}$ \\
\hline
\end{tabular}

\section{Kyrgyz Republic \\ Tourism Development Program until 2020:}

- Increase awareness about the Kyrgyz Republic as a tourism destination in the main traditional and potential tourist markets.

- Create a favorable regulatory environment for tourism development.

- Simplify the procedures for entry of foreign tourists.

- Introduce innovation cluster development of various types of tourism to enhance efficient and careful use of the country's tourism potential and to ensure year-round operation of the tourism industry.

- Ensure implementation of the Unified Register of Tourist Services and introduction of the quality measurement methodology.

- Modernize the basic components of the tourism infrastructure and bring them in line with international standards.

\section{Creating Awareness:}

- Conduct studies of the demand for tourist services and products.

- Establish mutually beneficial international cooperation in the tourism sector, at both national and regional levels.

- Create comprehensive structure of the tourism service network.

- Provide marketing promotion in $\mathrm{CIS}$ and other markets.

\section{Regulatory Environment:}

- Carry out a systematic analysis of regulations for tourism industry.

- Consider tax concessions for new enterprises, and other incentives to stimulate tourism development.

- Simplify procedure for the allocation and use of land for tourism product and facility development.

- Implement international tourism service standards at all tourist sites, and international standards of classification system of accommodation facilities.

\section{By 2020:}

- Increase in tourism's share of GDP by at least $7 \%$.

- Increase annual growth of inflow of tourists by $20 \%$. 
Appendix 1 Table continued

\begin{tabular}{|c|c|c|c|}
\hline Country & Priorities and/or Goals & Strategies & Targets \\
\hline $\begin{array}{l}\text { Kyrgyz } \\
\text { Republic }\end{array}$ & $\begin{array}{l}\text { - Ensure environmental protection } \\
\text { for the benefit of the local } \\
\text { community and stakeholders } \\
\text { of the tourism industry based } \\
\text { on assessment of natural } \\
\text { recreational capacity of existing } \\
\text { and potential tourism and } \\
\text { recreation zones. } \\
\text { - Stimulate positive attitudes } \\
\text { among residents toward foreign } \\
\text { tourists. } \\
\text { - Provide reliable safety for stay of } \\
\text { tourists in the Kyrgyz Republic. } \\
\text { - Transfer model of public } \\
\text { administration in the tourism } \\
\text { sector from "as it is" to "as it } \\
\text { should be" model. } \\
\text { - Develop personnel potential of } \\
\text { the tourism industry to meet } \\
\text { modern requirements. } \\
\text { - Actively promote tourism in } \\
\text { the regions of the country in } \\
\text { accordance with the national } \\
\text { strategic objectives. } \\
\text { - Improve tourism statistical } \\
\text { system. }\end{array}$ & 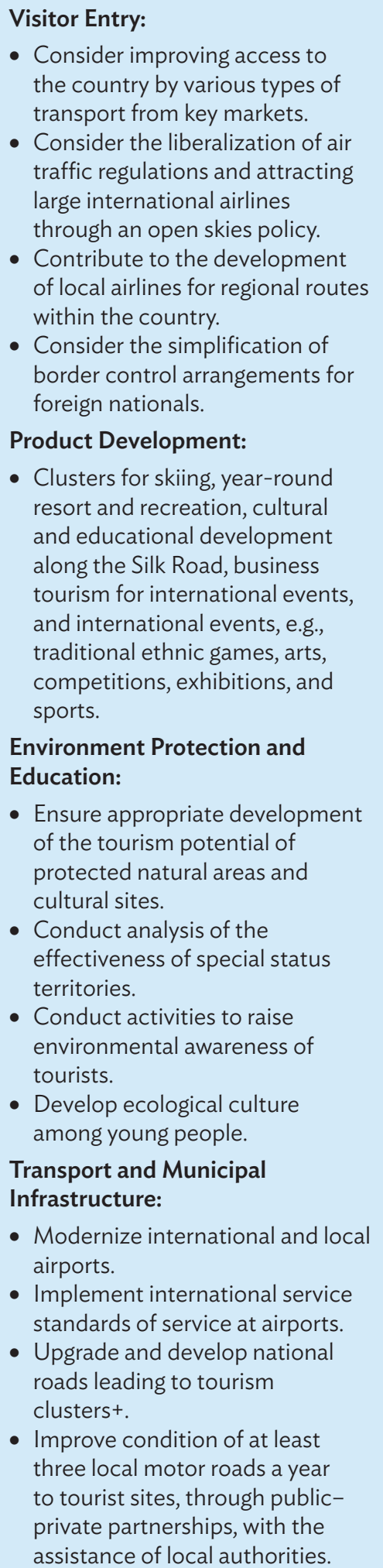 & \\
\hline
\end{tabular}


Appendix 1 Table continued

\begin{tabular}{ll} 
Country & \multicolumn{1}{c}{ Strategies } \\
Kyrgyz & - Develop regional and district \\
Republic & action plans on motor road \\
& infrastructure development, \\
& including service facilities and \\
& multilingual signage. \\
- & Construct and rehabilitate \\
& municipal infrastructure, as \\
& well as modernize of navigation \\
& systems to tourist sites and \\
& routes. \\
- Rehabilitate infrastructure for \\
waste water treatment at tourist \\
clusters and along tourist routes \\
to international standards.
\end{tabular}

\section{Positive Social Attitudes:}

- Conduct awareness-raising campaigns (through the media and educational institutions) and outreach programs, to improve the goodwill of the local population toward tourists.

- Ensure local community participation in planning and development of tourism infrastructure in their region.

Tourist Safety:

- Simplify the document verification procedure for foreign citizens by law enforcement agencies, except in cases of public safety threats.

- Create a Resort Police pilot project as part of the integrated safety system.

- Ensure compliance with the requirements of the International Ski Federation on safety of trails.

- Provide safety in the extreme tourism by optimizing the work of rescue teams.

- Improve travel insurance mechanisms.

\section{Public Administration:}

- Give appropriate status in the public administration system to the authorized tourism state body.

- Create a modern model of the authorized tourism state body in line with international requirements and standards, with sufficient financial allocation to improve the efficiency and effectiveness of its work. 
Appendix 1 Table

continued

Country

Priorities and/or Goals

Kyrgyz

Republic
Strategies

Targets

\section{Education and Training:}

- Realize measures for training and professional development in accordance with qualification of the labor market requirements of the tourism industry.

- Conduct independent evaluation of the skills of staff and graduates of tourism vocational educational institutions.

- Ensure cooperation of educational institutions and providers of tourism services through increasing the number of communication platforms in the form of conferences, educational events, and seminars.

- Promote the best practices of public-private partnerships in higher vocational education system to attract private companies to invest in future human resources and monitor the learning process in line with the needs of the tourist market.

\section{Regional Development in the}

\section{Country:}

- Identify priority types of tourism in accordance with the existing tourism potential of the regions.

- Develop regional tourism development programs and plans for their implementation, strengthening the role and involvement of local communities.

- Strengthen activities of tourism public areas in the region with the involvement of local government, business associations, and the tourism industry.

- Conduct international and national events in the regions.

- Improve tourism infrastructure in the regions.

- Create conditions for the development and promotion of traditional folk and craft products.

- Promote the historical and cultural heritage in the regions. 
Appendix 1 Table continued

\begin{tabular}{|c|c|c|}
\hline Country & Priorities and/or Goals & Strategies \\
\hline $\begin{array}{l}\text { Kyrgyz } \\
\text { Republic }\end{array}$ & & $\begin{array}{l}\text { Tourism Statistics: } \\
\text { - Review the existing statistical } \\
\text { tourism system relating to the } \\
\text { types of tourism. } \\
\text { - Develop a list and methodology } \\
\text { for collection and calculation of } \\
\text { additional tourism indicators in } \\
\text { accordance with the procedures } \\
\text { applied by international } \\
\text { organizations. } \\
\text { - Develop a methodology to } \\
\text { forecast tourism development } \\
\text { in accordance with the state } \\
\text { forecasting system. }\end{array}$ \\
\hline Mongolia & $\begin{array}{l}\text { The Government of Mongolia's } \\
\text { Operational Program for 2016- } \\
2020 \text { aims to "improve tourism } \\
\text { competitiveness at the regional } \\
\text { level, constitute the legal framework } \\
\text { and improvement effectiveness } \\
\text { in the economy" as well as the } \\
\text { following actions: } \\
\text { - Implement a comprehensive } \\
\text { policy for constituting legal } \\
\text { frameworks for tourism } \\
\text { development, cooperating with } \\
\text { international tourism networks, } \\
\text { developing infrastructure, and } \\
\text { improving quality of services. } \\
\text { - Formulate and implement } \\
\text { customized tourism subprograms } \\
\text { for municipal and regional areas. } \\
\text { - Support the establishment of } \\
\text { the Complex Tourism Center via } \\
\text { foreign investment cooperating } \\
\text { with public and private partners. } \\
\text { - Support building environment- } \\
\text { friendly parking and service areas } \\
\text { complying with international } \\
\text { standards in main tourism } \\
\text { regions. } \\
\text { - Support advertisement and } \\
\text { marketing of tourism in Mongolia, } \\
\text { improve capacity of tourism } \\
\text { services, and increase the number } \\
\text { of tourists. } \\
\text { principles, experience and } \\
\text { standards of international } \\
\text { tourism, build an adjunct } \\
\text { research and development unit, } \\
\text { and commission this unit to } \\
\text { implement multilateral projects. }\end{array}$ & $\begin{array}{l}\text { Infrastructure Development } \\
\text { - Coordinate road and } \\
\text { transportation policy with } \\
\text { tourism policy. } \\
\text { - Formulate price flexibility through } \\
\text { building a new airport and } \\
\text { increasing flight frequency and } \\
\text { destinations. } \\
\text { - Build tourism free-zone based in } \\
\text { the new airport. } \\
\text { - Establish temporary stopping } \\
\text { points and service areas nearby } \\
\text { main tourism routes. } \\
\text { Improvement of Tourism } \\
\text { Conditions: } \\
\text { - Build legal framework for online } \\
\text { visa services. } \\
\text { - Constitute legal framework for } \\
\text { one-time visa issuances and } \\
\text { entrances for border areas. } \\
\text { - Constitute legal framework for } \\
\text { preferred visa services for group } \\
\text { tourists. } \\
\text { - Formulate and implement } \\
\text { regional development plans. } \\
\text { - Support the development of } \\
\text { diversified products and services } \\
\text { in the provinces. } \\
\text { - } \text { - } \text { - } \text { sural Devevelopment: } \\
\text { services in the provinces and } \\
\text { advertise these abroad and at } \\
\text { home. }\end{array}$ \\
\hline
\end{tabular}

Targets

\section{By 2020}

The Government of Mongolia aims to achieve the following outcomes through the successful implementations of its objectives and actions:

- Improve Global Competitiveness Index from 99th place in 2015 to 90th place.

- Increase the total number of tourists from 386,206 (2015) to 1 million.

- Increase the tourism sector's contribution to GDP from 3.2\% in 2015 to $8.45 \%$ in 2020.

- Increase sector income from $\$ 265$ million to $\$ 1$ billion.

- Increase the estimated number of employees from 50,000 to 97,000 
Appendix 1 Table continued

\begin{tabular}{|c|c|c|}
\hline Country & Priorities and/or Goals & Strategies \\
\hline Mongolia & & $\begin{array}{l}\text { International Cooperation- } \\
\text { Development and Project } \\
\text { Implementation: }\end{array}$ \\
\hline
\end{tabular}

- Develop a tourism brand of "Traveling through Nomadic Roads" as actively participating in the Silk Road tourism programs.

- Build the Tourism Survey and Research Center, cooperating with the UNWTO.

- Build a transnational new tourism brand through implementing the "Tea Road" tourism projects with neighboring countries.

\section{Pakistan 11th Five-Year Plan 2013-2018:}

- National tourism policy to be formulated in consultation with provinces.

- Role of financial institutions in the sector will be enhanced in consultation with the State Bank of Pakistan.

- National Tourism Board to be established (with representation from private sector), with institutional capacity for implementation of the tourism policy.

- Public-private partnerships to be promoted.

- Sports and cultural shows to be arranged in different parts of the country to promote domestic tourism.

- Tourism product development to be taken-up on modern lines through a comprehensive tourism marketing plan.

- Cultural sites to be promoted as touristic attractions.

- System of accurate data collection and analysis to be established with necessary capacity-building and related activities undertaken.

- Women's participation in tourism activities to be encouraged.

- Private sector to be backed by the state through relaxation in taxation, surcharges, and creation of infrastructure and promotion.
Following abolition of the Ministry of Tourism in 2011, tourism policy and promotion were transferred to the provinces, each of which has its own organization responsible for tourism. The Pakistan Tourism Development Corporation (PTDC) is responsible for the national development of tourism.

PTDC stated ${ }^{\mathrm{b}}$ that key elements of the 12th Five-Year Plan 2018-2023, due to be published late 2018, will be:

- tourism infrastructure-building new and upgrading existing infrastructure;

- government departments that

- tourism services-provision of state-of-the-art services across the provinces; and

- image and branding-marketing and promotion to create a tourist friendly image. regulate tourism—restructuring;
There are no specific national tourism targets in the documents provided. At the moment, targets are being established at the provincial level in the tourism policy of each province. 
Appendix 1 Table continued

\begin{tabular}{|c|c|c|c|}
\hline Country & Priorities and/or Goals & Strategies & Targets \\
\hline $\begin{array}{l}\text { PRC } \\
\text { Autonomous } \\
\text { Region- } \\
\text { Inner } \\
\text { Mongolia }\end{array}$ & $\begin{array}{l}\text { 13th Five-Year Plan for Tourism } \\
\text { Industry in Inner Mongolia: } \\
\text { - Prioritize protection and } \\
\text { reasonable development. } \\
\text { - Establish the concept of "tourism } \\
\text { +" integrated development } \\
\text { concept, highlighting regional } \\
\text { characteristics. } \\
\text { - Transform and upgrade tourism } \\
\text { industry, focusing on quality and } \\
\text { efficiency. } \\
\text { - Adhere to market-oriented } \\
\text { principle, balancing the } \\
\text { relationship between government } \\
\text { and the market. } \\
\text { - Implement rural tourism to } \\
\text { reduce poverty. }\end{array}$ & $\begin{array}{l}\text { Development Planning: } \\
\text { - Develop a new pattern of } \\
\text { scientific planning for tourism } \\
\text { development, focusing on } \\
\text { whole-area tourism and four- } \\
\text { season tourism, deepen regional } \\
\text { tourism cooperation with the } \\
\text { opportunities of the Belt and } \\
\text { Road Initiative and other national } \\
\text { strategies, develop border } \\
\text { tourism experimental zones, and } \\
\text { prioritize tourism clusters based } \\
\text { on natural landscapes and ethnic } \\
\text { minority cultures. } \\
\text { Infrastructure: } \\
\text { - Develop public transportation } \\
\text { network and improve public } \\
\text { service. } \\
\text { Tourism Product Development: } \\
\text { - Develop tourism routes for } \\
\text { segments such as leisure, snow, } \\
\text { outdoor, culture, red revolution, } \\
\text { border and cross-border, action- } \\
\text { learning, and industrial tourism; } \\
\text { and develop featured tourism } \\
\text { souvenirs. } \\
\text { Marketing: } \\
\text { - Enhance branding and develop } \\
\text { festival and culture related } \\
\text { tourism brand. } \\
\text { Management and Standards: } \\
\text { establish industry standards, } \\
\text { enhance regulatory framework, } \\
\text { develop tourism talent } \\
\text { management system, and } \\
\text { increase government investment. }\end{array}$ & $\begin{array}{l}\text { By 2020: } \\
\text { - Tourism revenue: CNY530 billion } \\
\text { ( } \$ 77.1 \text { billion). } \\
\text { - Increase the total capacity of } \\
\text { tourism enterprises, and the } \\
\text { average consumption level of } \\
\text { tourists. } \\
\text { - Significant improvements in: the } \\
\text { strength of the tourism industry } \\
\text { system, the scale and benefits of } \\
\text { the tourism economy, the tourism } \\
\text { brand image, and the market } \\
\text { perception of "magnificent Inner } \\
\text { Mongolia" and the spread of } \\
\text { tourism to the central parts of the } \\
\text { region. } \\
\text { - Significantly improve the } \\
\text { role of tourism industry in } \\
\text { promoting economic and social } \\
\text { development. }\end{array}$ \\
\hline $\begin{array}{l}\text { PRC } \\
\text { Autonomous } \\
\text { Region- } \\
\text { Xinjiang } \\
\text { Uygur }\end{array}$ & $\begin{array}{l}\text { 13th Five-Year Plan for Tourism } \\
\text { Industry in Xinjiang Uygur: } \\
\text { - Develop and promote "tourism+" } \\
\text { integrated development and } \\
\text { "global tourism." } \\
\text { - Prioritize tourism training and } \\
\text { employment focused on the poor } \\
\text { rural population. } \\
\text { - Focus on tourism-related } \\
\text { publicity and promotion, and } \\
\text { brand cultivation. } \\
\text { Strive to develop the tourism } \\
\text { industry into a strategic pillar of the } \\
\text { economy. }\end{array}$ & $\begin{array}{l}\text { Development Planning: } \\
\text { - Multidisciplinary and integrated } \\
\text { tourism development planning } \\
\text { system, coordinated with overall } \\
\text { economic and social planning. } \\
\text { Tourism Product Development: } \\
\text { - Urumqi as the tourism hub of the } \\
\text { Silk Road Economic Belt; ethnic } \\
\text { culture tourism destination in } \\
\text { South Xinjiang; world heritage } \\
\text { tourism industry belt of Tian Shan } \\
\text { Mountain corridor; strengthen } \\
\text { development and production of } \\
\text { tourism souvenirs. }\end{array}$ & $\begin{array}{l}\text { By 2020: } \\
\text { - Total inbound tourists (PRC } \\
\text { and international): } 300 \text { million, } \\
\text { tourism-related consumption: } \\
\text { CNY600 billion ( } \$ 72.7 \text { billion). } \\
\text { - } 2.5 \text { million tourism employment, } \\
\text { with } 1 \text { million from poor rural } \\
\text { population. } \\
\text { - } 15 \text { National } 5 \text { A-level tourist } \\
\text { attractions and } 6 \text { National } \\
\text { Ecotourism Demonstration } \\
\text { Zones. }\end{array}$ \\
\hline
\end{tabular}


Appendix 1 Table continued

\begin{tabular}{ll} 
Country & \multicolumn{1}{c}{ Strategies } \\
PRC & Marketing: \\
Autonomous & - Establish system of statistics as \\
Region- & platform for tourism industry; \\
Xinjiang & improve branding and create new \\
Uygur & image for Xinjiang Uygur. \\
& Training: \\
- Strengthen human resource \\
development in tourism and \\
promote tourism-related \\
employment. \\
Investment and Finance: \\
- Increase investment in tourism \\
infrastructure; strengthen \\
financial support and promote \\
investment in tourism innovation; \\
establish a new mechanism for
\end{tabular}

\section{Tajikistan Goals in 2013 National Development Strategy:}

- Effective mechanism of state regulation and tourism support.

- Marketing strategy to increase tourism "visibility" of the country and increase tourism potential.

- Development of tourist products for domestic and foreign markets.

- International cooperation.

- Public-private sector dialogue.

- Tourism infrastructure.

- Tourism statistics improvement.

2018-2020 Tourism Development Program:

- Create favorable conditions for implementation of state policy in the tourism sector.

- Enhance the tourism market in the region and abroad.

- Wide-ranging state support.

\footnotetext{
Uzbekistan 2017-2021 State Policy for the Development of Tourism-Goals:

- Creation of favorable economic and legal conditions for the intensive and effective development of tourism as one of the strategic sectors the country's economy.

- Creation of a balanced supply of tourist services to facilitate the priority development of inbound and outbound tourism.
}

By 2020:

The Government of Tajikistan declared 2018, as the Year of Tourism and Folk Crafts in Tajikistan.

\section{Strategies from Tourism Development Program:}

- Develop infrastructure (including roads and rest areas).

- Develop new tourism products and routes.

- Bring operational standards to the international level, i.e., licensing system for tour operators, standards in tourist facilities.

- Improve quality of service, through training qualified staff.

- Attract investment in the sector, including 5-year tax exemption for new tourism ventures.

- Coordinate activities of tourism bodies and agencies.

\section{Strategic Priorities:}

- Improvement of legislation and legal framework aimed at creation of favorable conditions for domestic and foreign tourist activity.

- Development of the tourism industry in all regions of the republic, including related infrastructure to meet modern world standards.
- Increase numbers of tourists.

- Improve existing infrastructure.

- Create permanent and seasonal jobs.

- Increase level of investment and financial support.

There are no specific tourism targets in the documents provided. 
Appendix 1 Table continued

\begin{tabular}{lll} 
Country & \multicolumn{1}{c}{ Priorities and/or Goals } & \multicolumn{1}{c}{ Strategies } \\
Uzbekistan & - Ensuring the safety and security \\
of tourists in the tourist services & - Updating and diversification of \\
provided. & tourism products and services \\
- Integrated development of & targeted at different segments \\
all regions and sectors of the & of the tourist market, e.g., \\
economy to achieve sustainable & pilgrimage, cognitive, ecological, \\
growth in the share of the tourism & ethnographic, gastronomic, \\
sector in the country's GDP, & sports, therapeutic, agricultural, \\
the income of local and state & industrial, and commercial. \\
budgets, create new jobs, and & - Development of social tourism. \\
improve the standard of living and & Improved international \\
quality of life of the population. & cooperation in the field of \\
- Stimulation of tourism product & tourism activity. \\
development to take full & Promotion of the country's tourist \\
advantage of the country's & products to international and \\
extensive potential to develop & - Improvement of the system \\
different types of tourism. & of training qualified personnel \\
Creation in the market of the & for the tourism industry, skills \\
positive perception of the & upgrading, and retraining. \\
Republic of Uzbekistan as a & \\
tourism destination. &
\end{tabular}

$\mathrm{AZN}=$ Azerbaijan manat; $\mathrm{CIS}=$ commonwealth of Independent States; CNY = yuan; EU = European Union; GDP = gross domestic product; KZT = Kazakhstan tenge; MICE = meetings, incentives, conferences, and exhibitions; PRC = People's Republic of China; UNESCO = United Nations Educational, Scientific and Cultural Organization; UNWTO = United Nations World Tourism Organization.

a Exchange rate as of 10 December 2018.

b The Nation. 2018. New Tourism Policy Focuses on Infrastructure. 16 April. Islamabad.

Sources: Official tourism strategies and plans provided by CAREC countries. 


\section{APPENDIX 2 \\ Greater Mekong Subregion Strategic Direction Programs}

\section{GMS Tourism Cooperation Strategic Framework}

\begin{tabular}{|c|c|c|c|}
\hline $\begin{array}{l}\text { Strategic Direction } 1 \\
\text { Human Resource } \\
\text { Development }\end{array}$ & $\begin{array}{l}\text { Strategic Direction } 2 \\
\text { Improve Tourism } \\
\text { Infrastructure }\end{array}$ & $\begin{array}{c}\text { Strategic Direction } 3 \\
\text { Enhance Visitor Experiences \& } \\
\text { Services }\end{array}$ & $\begin{array}{l}\text { Strategic Direction } 4 \\
\text { Creative Marketing and } \\
\text { Promotion }\end{array}$ \\
\hline $\begin{array}{l}\text { Program } 1.1 \\
\text { Implement regional skills } \\
\text { standards }\end{array}$ & $\begin{array}{c}\text { Program } 2.1 \\
\text { Improve airports }\end{array}$ & $\begin{array}{l}\text { Program } 3.1 \\
\text { Create integrated spatial and } \\
\text { thematic destination plans }\end{array}$ & $\begin{array}{l}\text { Program } 4.1 \\
\text { Promote thematic } \\
\text { multicountry experiences and } \\
\text { events }\end{array}$ \\
\hline $\begin{array}{l}\text { Program } 1.2 \\
\text { Capacity bullding for public } \\
\text { officlals }\end{array}$ & $\begin{array}{l}\text { Program } 2.2 \\
\text { Improve road access in } \\
\text { secondary destinations }\end{array}$ & $\begin{array}{l}\text { Program } 3.2 \\
\text { Develop thematic multi- } \\
\text { country experiences }\end{array}$ & $\begin{array}{l}\text { Program } 4.2 \\
\text { Position the GMS as a must } \\
\text { visit destination in Asia }\end{array}$ \\
\hline $\begin{array}{l}\text { Program } 1.3 \\
\text { Strengthen tourism enterprise } \\
\text { support services }\end{array}$ & $\begin{array}{l}\text { Program } 2.3 \\
\text { Develop green urban } \\
\text { infrastructure and services }\end{array}$ & $\begin{array}{l}\text { Program } 3.3 \\
\text { Implement common tourism } \\
\text { standards }\end{array}$ & $\begin{array}{l}\text { Program 4.3 } \\
\text { Strengthen public-private } \\
\text { marketing arrangements }\end{array}$ \\
\hline & $\begin{array}{l}\text { Program } 2.4 \\
\text { Improve river and marine } \\
\text { passenger ports }\end{array}$ & $\begin{array}{l}\text { Program } 3.4 \\
\text { Facilitate private investment } \\
\text { in secondary destinations }\end{array}$ & $\begin{array}{l}\text { Program } 4.4 \\
\text { Enhance market research and } \\
\text { data exchange }\end{array}$ \\
\hline & $\begin{array}{l}\text { Program } 2.5 \\
\text { Expand the transnational } \\
\text { railway system }\end{array}$ & $\begin{array}{l}\text { Program } 3.5 \\
\text { Prevent negative social and } \\
\text { environmental impacts }\end{array}$ & $\begin{array}{l}\text { Program } 4.5 \\
\text { Raise awareness about } \\
\text { tourism opportunities and } \\
\text { sustainabllity }\end{array}$ \\
\hline
\end{tabular}

Strategic Direction 5

Facilitate Regional Travel

Program 5.1

Broaden implementation of air services agreements

Program 5.2 Address tourist visa policy gaps

Program 5.3

Improve border facilities and

management

GMS = Greater Mekong Subregion.

Source: Greater Mekong Subregion Presentation at the CAREC Regional Tourism Consultation Workshop. 23-24 October 2018. 


\section{APPENDIX3 \\ Thailand's System of Tourism Administration}

National Tourism Administration (NTA) + National Tourism Organization (NTO) Cooperative Approach

(i) NTA: Established in 2002, the Ministry of Tourism and Sports of Thailand promotes, supports and develops tourism, sports, sports education, recreation and other affairs as specified by law

(ii) NTO: Established in 1960, the Tourism Authority of Thailand (TAT) is an official government agency promoting tourism and providing tourism statistics

- Structure: Fifteen (15) departments-General Administration, Human Resources, Budget and Accounting, Finance, Planning, IT, Monitoring and Risk Management, Product Promotion, Events, Tourism Investment, Domestic Tourism, Asia and South Pacific Marketing, Europe, Africa, Middle East and Americans Marketing, and Advertising and Public Relations and Marketing Services with 850 employees (Headquarter-699 and 16 Overseas branches-35; and 22 regional offices-146)

- Budget - \$42.6 million (2015)

- The major goals are to implement Integrated Marketing Communication strategies; to conduct overseas marketing activities; to promote domestic tourism, to host international meetings, and collect and compile tourism-related data, and to implement tourism talent management strategies.

(iii) Chaired by the Minister of Tourism, the TAT Board of Directors is made up of 20 members representing both public and private sector of tourism and consults on tourism policies and TAT's key tasks. 


\section{APPENDIX 4 Survey Results}

CAREC Regional Workshop, Tashkent, Uzbekistan, 23-24 October 2018

Total number of survey forms submitted to the CAREC Secretariat: 33

\begin{tabular}{lc|}
\hline Country & No. of Forms Submitted \\
\hline Afghanistan & 1 \\
Azerbaijan & 3 \\
Georgia & 3 \\
Kazakhstan & 3 \\
\hline Kyrgyz Republic & 3 \\
\hline Mongolia & 3 \\
\hline Pakistan & 3 \\
\hline People's Republic of China & 3 \\
\hline Tajikistan & 3 \\
\hline Turkmenistan & 2 \\
Uzbekistan & 4 \\
\hline Others & 2 \\
\hline Total & 33 \\
\hline
\end{tabular}

a CAREC Institute and tour operator.

I. Question 1: Should a CAREC Tourism Working Group (TWG) be formed?

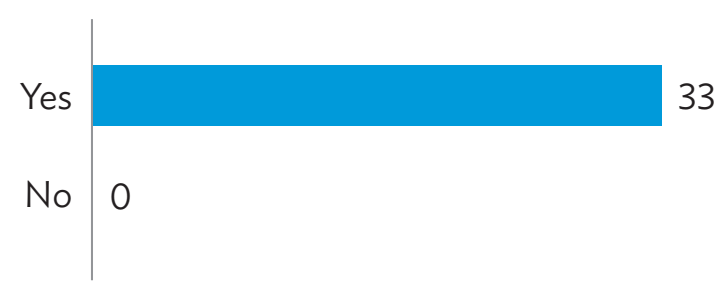


II. Question 2: What should be the composition of the TWG?

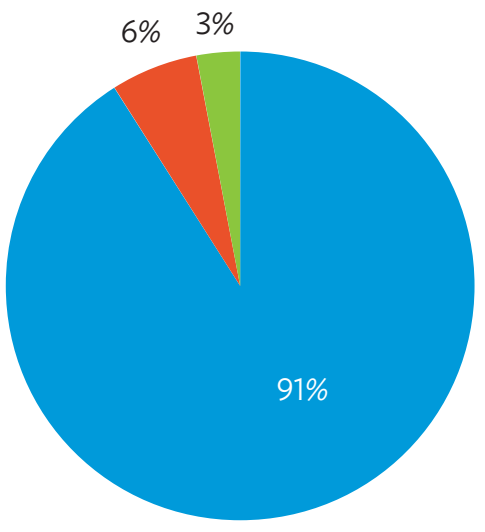

- Public officials + private sector representatives

- Public officials only

- Public officials + researchers

* Four countries highlighted other stakeholders in addition to public officials + private sector representatives. These include nongovernment organizations, local communities, destination management organizations, airlines, and visa authorities.

III. Question 3: What of the following activities that could be supported through a technical assistance (TA) grant do you consider relevant and in line with your country's needs and priorities? (several options can be selected)

Preparing a project pipeline

Developing standardized skills

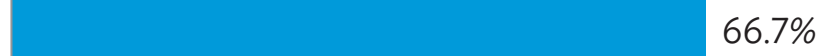

Improving tourism statistics

$57.6 \%$

Conducting marketing research

Supporting TWG's activities

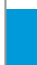

Identifying partnerships

Preparing a tourism strategy

$$
\begin{array}{|l}
\hline \\
\hline \\
\hline \\
\hline \\
\hline \\
\hline \\
\hline
\end{array}
$$

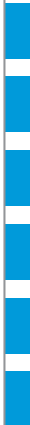

Assessing scope for visa harmonization

Others

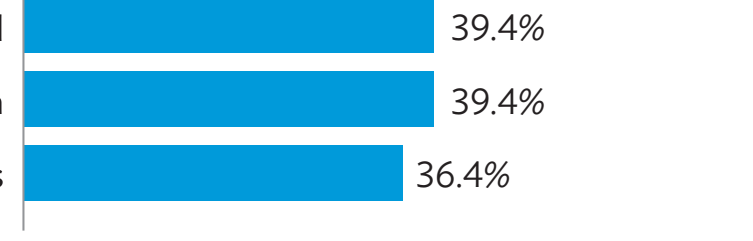




\section{Question 4: Are there any other areas that could be supported through a TA grant? ("others" in question 3)}

Twelve participants (five CAREC countries, tour operator, and $\mathrm{Cl}$ ) suggested additional areas to be supported under a TA grant. These include:

(i) providing support to existing intercountry routes (e.g., Modern Silk Road) in coordination with other development partners and regional initiatives;

(ii) enhancing tourism education, including training for tourist guides to help remove the language barriers;

(iii) conducting study visits both within and outside the region for in-depth knowledge of best practices;

(iv) developing tourism infrastructure;

(v) promoting sustainable and community-based tourism, particularly in remote and rural areas;

(vi) supporting pilot projects along the Almaty-Bishkek Economic Corridor (ABEC);

(vii) building the capacity of tourism-related agencies, including at the provincial level (e.g., Turkestan region under the new Shymkent-Tashkent-Khujand economic corridor, and Khujand);

(viii) organizing a CAREC Annual Tourism Conference and Expo to promote collaboration among public and private sector stakeholders; and

(ix) developing knowledge and research products. 


\section{Promoting Regional Tourism Cooperation under CAREC 2030}

\section{A Scoping Study}

The essence of tourism is to create and deepen socio-economic and cultural ties across countries, improve connectivity, and foster better dialogue by bringing people and nations closer together. Thus, promoting cooperation in the tourism sector is one of the operational priorities under the CAREC 2030 strategy. Tourism is also recognized as an effective way of helping developing countries take part in the global economy and achieve the Sustainable Development Goals. This scoping study seeks to assess the potential of CAREC as a platform to promote a regional approach to tourism development through the identification of opportunities for enhancing and expanding cooperation among member countries in the tourism sector, and to maximize economic opportunities while safeguarding ecosystems.

\section{About the Central Asia Regional Economic Cooperation Program}

The Central Asia Regional Economic Cooperation (CAREC) Program is a partnership of 11 member countries and development partners working together to promote development through cooperation, leading to accelerated economic growth and poverty reduction. It is guided by the overarching vision of "Good Neighbors, Good Partners, and Good Prospects." CAREC countries include: Afghanistan, Azerbaijan, the People's Republic of China, Georgia, Kazakhstan, the Kyrgyz Republic, Mongolia, Pakistan, Tajikistan, Turkmenistan, and Uzbekistan.

\section{About the Asian Development Bank}

ADB is committed to achieving a prosperous, inclusive, resilient, and sustainable Asia and the Pacific, while sustaining its efforts to eradicate extreme poverty. Established in 1966, it is owned by 67 members- 48 from the region. Its main instruments for helping its developing member countries are policy dialogue, loans, equity investments, guarantees, grants, and technical assistance.

$\mathrm{ADB}$

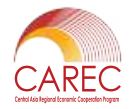

CAREC SECRETARIAT

Www.carecprogram.org

\section{ASIAN DEVELOPMENT BANK}

6 ADB Avenue, Mandaluyong City 1550 Metro Manila, Philippines

www.adb.org 